(c) The Author(s), 2021. Published by Cambridge University Press on behalf of The Nutrition Society. This is an Open Access article, distributed under the terms of the Creative Commons Attribution licence (http://creativecommons.org/licenses/by/4.0/), which permits unrestricted re-use, distribution, and reproduction in any medium, provided the original work is properly cited

\title{
Zinc deficiency as a possible risk factor for increased susceptibility and severe progression of Corona Virus Disease 19
}

\author{
Inga Wessels ${ }^{1}$, Benjamin Rolles ${ }^{2}$, Alan J. Slusarenko ${ }^{3}$ and Lothar Rink ${ }^{1 *}$ \\ ${ }^{1}$ Institute of Immunology, Faculty of Medicine, RWTH Aachen University Hospital, Pawwelsstr. 30, 52074 Aachen, Germany \\ ${ }^{2}$ Department of Hematology, Oncology, Hemostaseology and Stem Cell Transplantation, Faculty of Medicine, RWTH Aachen \\ University Hospital, Pauwelsstrasse 30, 52074 Aachen, Germany \\ ${ }^{3}$ Department of Plant Physiology, RWTH Aachen University, Worringer Weg 1, 52074 Aachen, Germany
}

(Submitted 30 July 2020 - Final revision received 7 January 2021 - Accepted 21 February 2021 - First published online 1 March 2021)

Abstract

The importance of $\mathrm{Zn}$ for human health becomes obvious during $\mathrm{Zn}$ deficiency. Even mild insufficiencies of Zn cause alterations in haematopoiesis and immune functions, resulting in a proinflammatory phenotype and a disturbed redox metabolism. Although immune system malfunction has the most obvious effect, the functions of several tissue cell types are disturbed if Zn supply is limiting. Adhesion molecules and tight junction proteins decrease, while cell death increases, generating barrier dysfunction and possibly organ failure. Taken together, Zn deficiency both weakens the resistance of the human body towards pathogens and at the same time increases the danger of an overactive immune response that may cause tissue damage. The case numbers of Corona Virus Disease 19 (COVID-19) are still increasing, which is causing enormous problems for health systems and economies. There is an urgent need to reduce both the number of severe cases and the resulting deaths. While therapeutic options are still under investigation, and first vaccines have been approved, cost-effective ways to reduce the likelihood of or even prevent infection, and the transition from mild symptoms to more serious detrimental disease, are highly desirable. Nutritional supplementation might be an effective option to achieve these aims. In this review, we discuss known Zn deficiency effects in the context of an infection with Severe Acute Respiratory Syndrome-Coronavirus-2 and its currently known pathogenic mechanisms and elaborate on how severe pre-existing Zn deficiency may pre-dispose patients to a severe progression of COVID-19. First published clinical data on the association of Zn homoeostasis with COVID-19 and registered studies in progress are listed.

Key words: Zinc deficiency: Corona Virus Disease 19: Severe Acute Respiratory Syndrome-Coronavirus-2: Impaired immune system

In March 2020, the WHO declared the Corona Virus Disease 19 (COVID-19) to be a pandemic ${ }^{(1)}$. Infections with Severe Acute Respiratory Syndrome-Coronavirus-2 (SARS-CoV-2) can be asymptomatic ( $40 \%$ of the cases) or cause a mild illness ( $40 \%$ ), but in about $15 \%$ of the cases, severe disease develops, characterised by clinical signs of pneumonia (fever, cough and dyspnoea) plus one of the following: respiratory rate $>30$ breaths/ min; severe respiratory distress or $\mathrm{SpO}_{2}<90 \%$ on room air as defined by the WHO. Patients with acute respiratory distress syndrome (ARDS), sepsis or septic shock are categorised as critically ill which is the case in about $5 \%$ of the cases ${ }^{(2)}$. Amongst the comorbidities, resulting in severe COVID-19 progression, inappropriate nutrition is increasingly attracting attention ${ }^{(3)}$. According to the WHO, 1.9 billion adults are overweight or obese, while 462 million are underweight ${ }^{(4)}$, underlining the relevance of taking inappropriate nutrition into account when discussing prevention and treatment of COVID-19. It is important to mention that Zn deficiency is frequently observed in undernutrition as well as in obesity, although the underlying mechanisms are different ${ }^{(5)}$.

In a previous article, we drew attention to the strong overlap of risk groups for severe progression of COVID-19 with the groups where $\mathrm{Zn}$ deficiency is frequently diagnosed ${ }^{(6)}$. The effects of $\mathrm{Zn}$ supplementation were described and discussed ${ }^{(6,7)}$. In this article, we would like to discuss how pre-existing Zn deficiency might increase the susceptibility to COVID-19 infections as well as pre-dispose individuals for severe progression of disease as summarised in Fig. 1. Despite the many improvements in $\mathrm{Zn}$ research, we still lack a valid biomarker to reliably assess the $\mathrm{Zn}$ status of an individual ${ }^{(8,9)}$. Serum or plasma $\mathrm{Zn}$ levels are often used but are not completely reliable. Thus, serum levels below $642.5 \mu \mathrm{g} / \mathrm{l}$

Abbreviations: ARDS, acute respiratory distress syndrome; COVID-19, Corona Virus Disease 19; PMN, polymorphonuclear neutrophils; ROS, reactive oxygen species; SARS-CoV-2, Severe Acute Respiratory Syndrome-Coronavirus-2.

* Corresponding author: Dr Lothar Rink, email LRink@ukaachen.de 
ZA

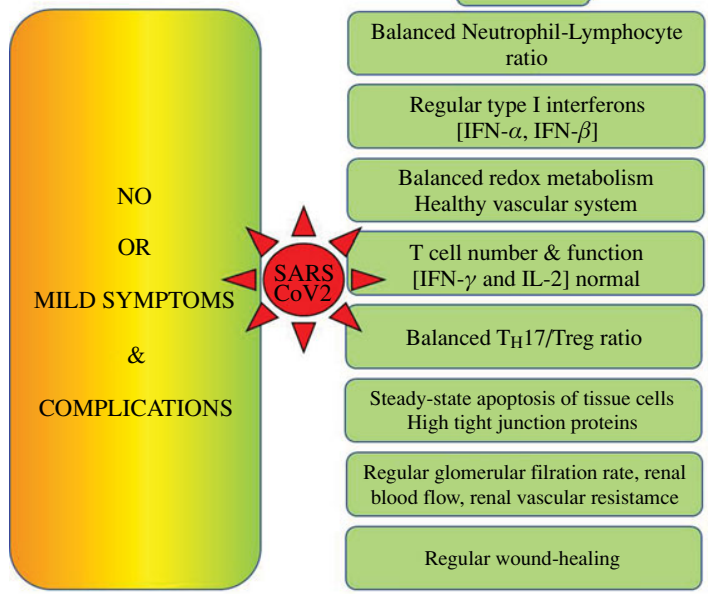

Severe Disease Mild symptoms

uninfected
ZD

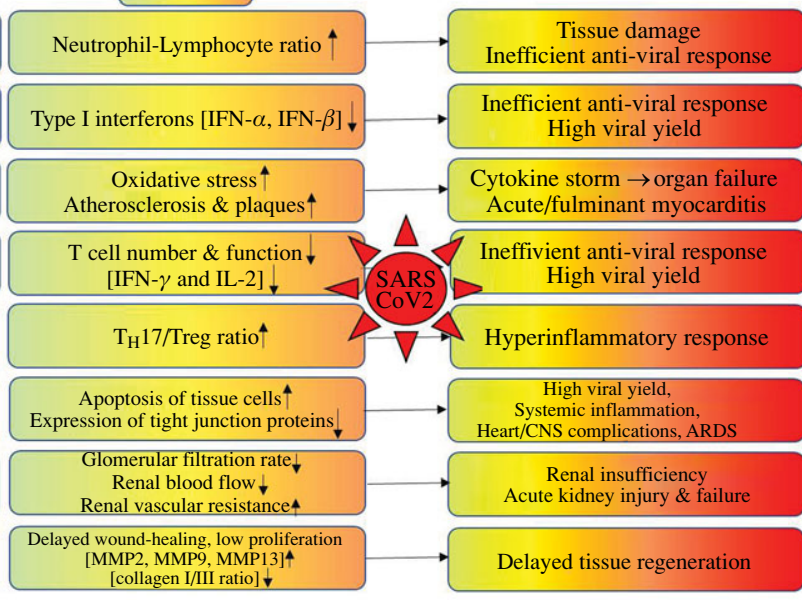

Mild symptoms Severe Disease

Fig. 1 Summary of complications that can be expected in patients with pre-existing zinc deficiency, when challenged by Severe Acute Respiratory SyndromeCoronavirus-2 (SARS-CoV-2). A patient with no co-morbidities and a balanced zinc homoeostasis will most likely develop no or mild symptoms or complications if infected with SARS-CoV-2 because immune cell numbers and functions are balanced, as are the other parameters listed in the Figure. However, zinc deficiency alone will result in the alterations indicated in the Figure. Preconditions resulting from zinc deficiency may result in the development of severe symptoms, critical illness and even death if the patient becomes infected with SARS-CoV-2. ARDS, acute respiratory distress syndrome; CNS, central nervous system; IFN, interferon; MMP, matrix metalloproteinase; $T_{H}, T$ helper cell; $T_{\text {reg, }}$, regulatory $T$ cell; $Z A$, zinc adequate; $Z D$ : zinc deficient.

are taken as an indication of Zn deficiency, but only partially reflect intracellular concentrations and the $\mathrm{Zn}$ status of an individual. Therefore, clear clinical signs of $\mathrm{Zn}$ deficiency can be observed even if serum $\mathrm{Zn}$ levels are above this critical value or in the normal range. Circadian variations of serum $\mathrm{Zn}$ levels were observed, and serum $\mathrm{Zn}$ also depends upon recent food intake and the degree of hydration/dehydration of an individual $^{(10,11)}$. Early effects of $\mathrm{Zn}$ deficiency are often general and include functional changes that can be associated with various diseases. For this reason, mild Zn deficiency can be 'hidden'(8) Functional deficiencies in Zn-dependent immunological processes have been shown in human subjects and mice without any significantly different serum or plasma $\mathrm{Zn}$ levels compared with controls ${ }^{(12-14)}$. Currently, $\mathrm{Zn}$ deficiency is mostly defined by using a combination of clinical symptoms, calculating $\mathrm{Zn}$ and phytate intake from food and measuring immunological changes ${ }^{(15,16)}$. For growing infants $(<2$ years) and children $(<5$ years), the 'height-for-age ratio' should be determined as an additional parameter ${ }^{(17)}$. Moreover, it has been suggested that serum and plasma $\mathrm{Zn}$ values need to be adjusted for situations where inflammation is present ${ }^{(18,19)}$. For these reasons, $\mathrm{Zn}$ deficiency is often investigated using animal models of severe and induced Zn deficiency and well-defined low-Zn diets. Alternatively, Zn deficiency can reliably be modelled in cell cultures with either Zn-depleted media or by using Zn-specific chelators. Whether the latter rather models severe or mild Zn deficiency in the context of the whole organism is hard to predict. In this review, we describe data derived from clearly Zn-deficient humans and mice. Individuals with subclinical Zn deficiency might be less severely affected, but the effects are probably still not negligible ${ }^{(20)}$. The consequences of $\mathrm{Zn}$ deficiency are manifold ${ }^{(16,21-24)}$, and only effects that are relevant regarding the susceptibility and progression of infectious diseases such as COVID-19 (Fig. 1) are included here. In regard to innate immunity, the article will focus on the effects of $\mathrm{Zn}$ on the integrity of the epithelial cell barriers, on neutrophil and macrophage maturation and functions, and in regard to adaptive immunity, we focus on lymphocyte maturation and differentiation, and cytokine and antibody production. Known effects of Zn deficiency on the vascular system and the association of those effects with diseases affecting the heart, kidney, central nervous system and intestine are described in relation to COVID-19.

In addition to nutritional causes (undernutrition, malnutrition, veganism, geophagy, a phytate-rich diet, low-Zn parenteral nutrition), conditioned $\mathrm{Zn}$ deficiency has been observed in association with many diseases and inflammatory reactions ${ }^{(18,25)}$. Attention was drawn to $\mathrm{Zn}$ deficiency in the 1960s due to a traditional soil-eating diet (geophagy) in a group in Iran leading to a severe $\mathrm{Zn}$ deficiency associated with dwarfism. The group revealed that a severely disturbed immune response, was more susceptible to infection, suffered from lethargy, and none survived beyond the age of 25 years ${ }^{(16)}$. Untreated severe $\mathrm{Zn}$ deficiency, such as that seen during acrodermatitis enteropathica, has a high mortality rate often because of the inefficient clearance of infections ${ }^{(26)}$. The subjects with acrodermatitis enteropatbica, and the above-described group in Iran, suffered from severe $\mathrm{Zn}$ deficiency. However, studies in mice and human subjects have shown that detrimental effects are seen not only in severe $\mathrm{Zn}$ deficiency but that also a slight to moderate $\mathrm{Zn}$ deficiency can result in alterations of haematopoiesis and defects in 
the functions of immune cells ${ }^{(12-14,27)}$, which thus increases the susceptibility to infection. It is important to recall that the immune system is affected negatively by $\mathrm{Zn}$ deficiency before any other symptoms become obvious and before serum $\mathrm{Zn}$ levels drop below $642.5 \mu \mathrm{g} / \mathrm{l}^{(28)}$. Besides being essential for a robustly functioning immune system, $\mathrm{Zn}$ is also important for DNA synthesis, cell proliferation, cell differentiation, apoptosis, protein structure, protein-protein interactions and signal transduction as a second messenger for all kinds of cells. In the nervous system, Zn serves as an individual neurotransmitter that is secreted into the synaptic cleft ${ }^{(29-33)}$. Zn deficiency can manifest itself in a variety of ways; amongst others, there are increased frequencies of pneumonia and diarrhoea, an altered sense of smell and taste, cytopenia, poor wound healing, hair thinning, eczema, reduced fertility, increased fatigue, sicca syndrome and nail dysplasia ${ }^{(22)}$. Zn deficiency is a significant public health problem, and high numbers of deaths worldwide, especially in children, are associated with severe $\mathrm{Zn}$ deficiency ${ }^{(8,24,34,35)}$.

The magnitude of the effects of a pre-existing Zn deficiency, and the significance of mild compared with severe $\mathrm{Zn}$ deficiency, remains to be clearly defined and clarified in relation to COVID-19. A series of studies have been registered to analyse retrospectively the serum $\mathrm{Zn}$ levels of patients (online Supplementary Table S1), and the first published data in this regard are starting to appear. Data from further registered studies, investigating prophylactic $\mathrm{Zn}$ supplementation to decrease the susceptibility for infections and severe disease, especially in medical and military personnel, are also underway (online Supplementary Table S1). In the absence of experimental data, we extrapolate the information from the existing literature, in anticipation of the data from clinical studies, which should soon be available (online Supplementary Table S1).

Zinc deficiency alters haematopoiesis and disturbs the balance of innate and adaptive immune cells largely to the detriment of cells from the lymphoid lineage

Severe infections with SARS-CoV-2 can cause major hematopoietic changes. Most prominently, a decrease in lymphocytes has been noted, especially affecting the T cells. In COVID-19 patients with severe symptoms, the reduction in number and the functional exhaustion of $\mathrm{CD}^{+}{ }^{+}$as well as $\mathrm{CD}^{+}{ }^{+} \mathrm{T}$ cells, as detected by elevated expression of Tim- 3 and PD-1, is frequently described and observed early during disease ${ }^{(36,37)}$. The recovery of T cell numbers in severely ill patients was paralleled with the improvement of the symptoms and with positive prognosis and survival ${ }^{(38)}$

Available data on the effects of SARS-CoV- 2 on $\mathrm{CD}^{+}{ }^{+}$compared with $\mathrm{CD}^{+}{ }^{+} \mathrm{T}$ cells are somewhat controversial. While, in one study, no significant difference in the $\mathrm{CD}^{+}: \mathrm{CD}^{+}$ratio but increased expression of $\mathrm{CD}^{+}$was found ${ }^{(39)}$, other studies have reported a decrease particularly of $\mathrm{CD}^{+} \mathrm{T}$ cells, or a significantly elevated CD4:CD8 ratio in COVID-19 patients ${ }^{(37,38,40)}$. As high levels of either perforin or granulysin, or both, were detected in $\mathrm{CD}^{+}$ $\mathrm{T}$ cells ${ }^{(41)}$, it can be assumed that $\mathrm{CD}^{+}$cells are overreacting initially and are subject to exhaustion and apoptosis at later stages. However, this hypothesis remains to be addressed. In contrast, B cell numbers and serum levels of Ig (IgA, IgG and IgM) have been reported to be rather weakly affected during COVID-19(38).

Haematopoiesis is severely disturbed during both severe and mild Zn deficiency, which was found in human and animal studies as illustrated in Fig. 2. Especially, a loss in pre-B cells and immature B cells, as well as early developmental T cells, including CD4/CD8 double positive and pre-T cells, was described for humans and rodents with Zn deficiency as diagnosed by low plasma $\mathrm{Zn}$ levels. These effects can be corrected by $\mathrm{Zn}$ supplementation, as shown in subjects over 65 years of age suffering from mild serum $\mathrm{Zn}$ deficiency and in obese subjects with decreased serum $\mathrm{Zn}$ levels ${ }^{(5,16,27,42-44)}$. Several mechanisms were described to underlie this decrease in cell numbers. Most importantly, thymus atrophy and decreased serum concentration of thymulin, which is necessary especially during maturation of $\mathrm{T}$ cells ${ }^{(45,46)}$, and lower levels of growth factors such as IL-2 (T cells) were reported in individuals with decreased serum $\mathrm{Zn}$ levels, and a disruption of IL-2 signalling was found when analysing cell cultures, where cellular $\mathrm{Zn}$ was depleted using a $\mathrm{Zn}$ chelator ${ }^{(47)}$. During dietary $\mathrm{Zn}$ deprivation in humans and rodents, a decreased ratio of type 1 :type 2 T-helper cells, with reduced production of T-helper type 1 cytokines like interferon $\gamma$, is observed due to increased apoptosis ${ }^{(16,30,44)}$. Assuming that a Zn-deficient individual has fewer $\mathrm{B}$ cells compared with a person with a balanced $\mathrm{Zn}$ homoeostasis, a decreased generation of pathogen-specific antibodies can be expected. This might suggest that individuals, especially with a pre-existing severe $\mathrm{Zn}$ deficiency, would not be able to generate a sufficiently strong antibody response against SARS-CoV-2 $2^{(48,49)}$

In COVID-19 patients, especially those with severe symptoms, $\mathrm{T}_{\mathrm{H}} 17$ cell numbers were elevated, which is in line with the hyperinflammatory status of the immune system ${ }^{(41)}$. Recent studies underline that differentiation into the main $\mathrm{CD}^{+}{ }^{+}$cell subtypes is disturbed when $\mathrm{Zn}$ supply is low. In vivo data from patients with allergic asthma reveal that impaired $\mathrm{T}_{\text {reg- }}{ }^{-}$ mediated suppression can be correlated with decreased serum $\mathrm{Zn}$ levels ${ }^{(50)}$. Data from in vitro differentiation experiments, using Zn-deficient compared with Zn-adequate culture medium, further strengthen the hypothesis, that development of proinflammatory $\mathrm{T}_{\mathrm{H}} 17$ cells is supported as a consequence of $\mathrm{Zn}$ deficiency ${ }^{(51)}$.

In contrast to the consistently observed lymphopenia in COVID-19 patients, the numbers of myeloid cells in the blood and in lung tissue were strongly elevated. Neutrophilia was associated with the progression of severe disease to ARDS and with increased mortality therefrom, similarly to that described for bacteria-induced lung injury ${ }^{(52-55)}$. As blood analyses of non-survivors revealed severe lymphopenia combined with significantly elevated numbers of neutrophils, the neutrophil:lymphocyte ratio was suggested as a prognostic marker for COVID-19 patients ${ }^{(38,55)}$. Similar to the neutrophil:lymphocyte ratio shift in COVID-19 patients, the balance between adaptive and innate immune cells is shifted towards the latter during $\mathrm{Zn}$ deficiency. Investigation of severely $\mathrm{Zn}$-deficient rodents, that were fed on a low-Zn diet, showed high numbers of neutrophils and their specific products in the bone marrow and blood compared with Zn-adequate animals ${ }^{(49,56,57)}$. Our own unpublished results suggest that maturation of myeloid precursors into granulocytes in 


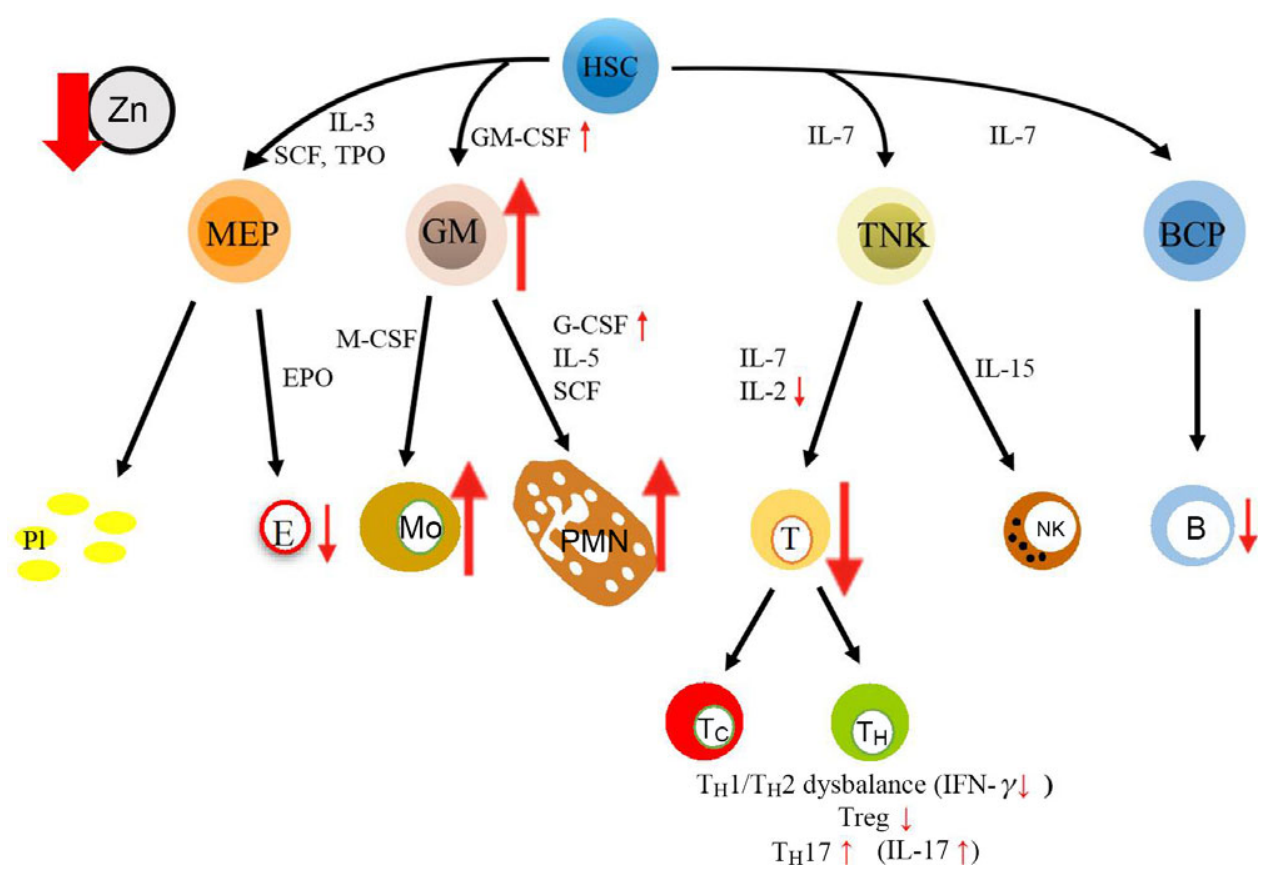

Fig. 2 Alterations in haematopoiesis are reported during zinc deficiency as well as in Corona Virus Disease 19 (COVID-19). During zinc deficiency, indicated by the red arrow, differentiation of myeloid cells, including polymorphonuclear neutrophils (PMN) and monocytes (Mo), is prioritised over development of adaptive immune cells, this especially impacts T cells $(T)$. Amongst others, the prioritisation of myeloid cells may be explained by changes in growth factor expression: granulocyte-macrophage colony-stimulating factor (GM-CSF) and granulocyte-colony-stimulating factor (G-CSF) were described to be highly expressed, while levels of IL-2 are decreased during zinc deficiency. Furthermore, the Thelper cell $\left(T_{H}\right) 1: T_{H} 2$ ratio is imbalanced during zinc deficiency, Th17 cell numbers are increased, while regulatory $T$ cell $\left(T_{\text {reg }}\right)$ numbers were described as decreased as well as their functions. Most of those haematopoietic disturbances found during zinc deficiency are generally described for COVID-19 patients, as detailed in the text. B, B cell; BCP, B-cell progenitor; E, erythrocyte; EPO, erythropoietin; GM, granulocyte-macrophage progenitor; HSC, hematopoietic stem cell; MEP, megakaryocyte-erythroid progenitor; NK, natural killer cell; PI, platelets; SCF, stem cell factor; $\mathrm{T}_{\mathrm{C}}$ : cytotoxic T cell; TNK, T and NK cell progenitor; TPO, Thrombopoietin.

Zn-deficient human cell cultures is also increased compared with cells that differentiate in Zn-adequate cell cultures, while Zn supplementation attenuates the development into mature neutrophils ${ }^{(58)}$. As an underlying mechanism, the increased response to growth factors, for example, to the granulocyte-macrophage colony-stimulating factor and granulocyte-colony-stimulating factor, can be named, as was determined in cell culture experiments where $\mathrm{Zn}$ was added to the culture medium ${ }^{(54,59)}$.

Thrombocytopenia, which we will come back to later, and a decline in $\mathrm{Hb}$ are also common in COVID-19 patients ${ }^{(37)}$. Lower $\mathrm{Hb}$ and erythrocyte counts were found in severe COVID-19 cases compared with moderate cases. Furthermore, higher ferritin was found in severe COVID-19 cases, and a significant difference in the mean ferritin levels was found between survivors and non-survivors ${ }^{(60)}$. Additional research is necessary to prove the suggested important role of anaemia and a disturbed Fe in severe cases of COVID-19. This might uncover new treatment options.

Alterations in bone marrow metabolism were related to decreased serum $\mathrm{Zn}$ concentrations in humans ${ }^{(21,61)}$. This finding together with the observation that the osmotic fragility of erythrocyte membranes is elevated in animals with dietary $\mathrm{Zn}$ deficiency, as are levels of lipid peroxidation in mitochondrial and microsomal membranes, suggests that there might be some interconnection between $\mathrm{Zn}$ deficiency and anaemia ${ }^{(62)}$. Indeed, serum hypozincaemia is commonly observed in anaemic subjects $^{(61,63-66)}$. However, importantly, a causal association between $\mathrm{Zn}$ deficiency and anaemia has so far not been established clearly and is discussed controversially. For example, serum Zn concentration was correlated with serum ferritin concentration in patients undergoing peritoneal dialysis ${ }^{(67)}$. Morover, lower serum ferritin was significantly correlated with smaller sizes of $\mathrm{Zn}$ pools in premenopausal women, although without anaemia ${ }^{(68)}$. Regarding the effects of adjuvant $\mathrm{Zn}$ therapy for improving anaemia in haemodialysis patients, $\mathrm{Hb}$ levels were found to increase significantly in Zn-supplemented patients compared with patients not supplemented with $\mathrm{Zn}$. The authors suggest a 'zinc deficiency anemia', which needs further evaluation $^{(64)}$. In this regard, it should be pointed out that nutritional deficits often include several elements concomitantly, as shown for $\mathrm{Zn}$ and Fe, Se and others ${ }^{(10,63,65,69)}$. Since the association of anaemia with an increased risk and severe progression of COVID-19 has not been clearly established, this will not be discussed further in this article. However, as anaemia is generally related to poor outcomes of infectious diseases ${ }^{(70)}$, possible nutritional deficits in COVID-19 risk groups should be addressed and not only Zn but also Fe, Se and other elements might need to be supplemented if applicable.

Comparing the disturbance of haematopoiesis observed in individuals with low serum Zn levels or with COVID-19, various congruencies become apparent. As lymphopenia, neutrophilia and a decline in $\mathrm{Hb}$ are associated with progression to severe COVID-19, it can be hypothesised that a pre-existing severe Zn deficiency will predispose patients to stronger progression of infections with SARS-CoV-2 and that even a mild Zn deficiency 
should be corrected to prevent more severe progression of the viral infection. A pre-existing elevated neutrophil:lymphocyte ratio, even one of low magnitude, as during Zn deficiency, might be detrimental in the case of severe and aggressive infections such as COVID-19. At first sight, elevated numbers of innate immune cells as a first line of defence might appear beneficial. However, they are easily overrun during viral infections as a specific response, and the release of anti-viral factors and antibodies, especially by adaptive immune cells, is of major importance here. The elevated numbers of hyperactivated innate immune cells can even lead to high levels of inflammatory factors and oxidative stress causing destruction of host tissue. In SARS-CoVinfected mice, the recruitment of high numbers of monocytes and macrophages to the lungs was observed, secreting high numbers of proinflammatory cytokines and chemokines, which are associated with vascular leakage, underlining the detrimental effect of highly reactive immune cells ${ }^{(71)}$. Similar scenarios are suggested for SARS-CoV-2 in humans ${ }^{(72-74)}$.

The next chapters will show that the alterations in immune cell counts are not the only indication of an association between Zn deficiency and COVID-19.

\section{Pre-existing zinc deficiency could prime for the cytokine} release syndrome

A frequent complication among patients with severe COVID-19 is the cytokine release syndrome, which spreads throughout the body from the focal infected area and may lead to death because of subsequent ARDS or multiple organ dysfunction syndrome and other complications ${ }^{(75,76)}$. It was reported that among the COVID-19 patients, the classic serum proinflammatory cytokines like TNF- $\alpha$, IL-2, IL-6, IL-7, IL-8, IL-10, granulocyte-colony-stimulating factor and C-reactive protein are elevated ${ }^{(72,73,76)}$. IL-6 in particular, which is produced by lung resident macrophages and circulating immune cells ${ }^{(77-79)}$, has been associated with severe COVID-19 and increased mortality ${ }^{(80)}$. Moreover, D-dimers, ferritin, lactate dehydrogenase, aspartate aminotransferase, alanine aminotransferase and soluble CD25 (IL-2 receptor) are increased, while fibrinogen is decreased ${ }^{(72)}$.

Although there are planned and ongoing trials to counter the cytokine storm using approved antibodies such as tocilizumab (anti-IL-6 receptor), anakinra (IL-1 receptor antagonist, IL-1RA) and anti-TNF antibodies used to treat other hyperinflammatory conditions, and in spite of some benefits, so far their efficacy was not proven in large-scale, randomised controlled trials ${ }^{(72,81-83)}$, and therefore, therapeutic options are still limited.

In recent years, in vivo and in vitro data supporting the hypothesis that a pre-existing $\mathrm{Zn}$ deficiency augments the activation-induced inflammatory response, and results characterizing the possible underlying mechanisms, are constantly accumulating. Serum hypozincaemia was correlated with increased serum levels of, amongst others, IL-1 $\beta$, IL- 6 , TNF $\alpha$, IL-8, granulocyte-colony-stimulating factor, IL-10, IL-1RA, IL-17, C-reactive protein and calprotectin; thus, a whole battery of proinflammatory mediators is increased, especially during severe $\mathrm{Zn}$ deficiency, and particularly in combination with the inflammatory response to a pathogen ${ }^{(54,84-88)}$. In the case of
IL-1 $\beta$ and TNF $\alpha$, Zn chelation was shown to induce epigenetic changes in the promoters of both genes in cell culture experiments. More specifically, the accessibility of regions in the DNA close to the transcriptional start site was significantly increased so that after inflammatory activation of the cells, by, for example, lipopolysaccharide, gene expression was augmented $^{(88)}$. Moreover, activation of $\mathrm{NF} \kappa \mathrm{B}$ a central player in the signalling pathways involved in the generation of inflammatory factors is increased when $\mathrm{Zn}$ is limiting, as found in mice with diet-induced serum hypozincaemia ${ }^{(87)}$. Cell culture experiments using Zn-depleted medium revealed increased expression of calprotectin in myeloid precursors and mature monocytic cells ${ }^{(89)}$

Activated T cells express lower IL-2 and interferon $\gamma$ mRNA levels, as was shown in vitro and observed in individuals with low serum $\mathrm{Zn}^{(90)}$. IL-2 is essential for natural killer cell and cytotoxic $\mathrm{T}$ lymphocyte activity. Interferon $\gamma$ is essential for killing viruses, parasites and bacteria. Thus, the decreased efficiency of the immune response in Zn-deficient subjects is easily explained $^{(14,90,91)}$. Defects in $\mathrm{T}$ cell function as a consequence of $\mathrm{Zn}$ deficiency can also be explained by the accumulation of deoxyguanosine, which results from decreased $\mathrm{Zn}$-dependent nucleoside phosphorylase activity in human lymphocytes, derived from human Zn-deficient volunteers before and after Zn supplementation ${ }^{(92)}$. Serum Zn deficiency strongly affects Th1 cells, while Th2 cells are largely unaffected, and production of IL-4, IL-6 and IL-10 (Th2 cytokines) remains rather stable. However, production of interferon $\gamma$ and IL-2 (Th1 cytokine) is decreased $^{(93)}$.

Although Treg cell numbers might be constant, or even elevated, during in vitro differentiation under $\mathrm{Zn}$ deficiency, it was suggested that their function is disturbed ${ }^{(51)}$. In vivo data are so far scarce, but some studies in mice suggest decreased transforming growth factor $\beta$ (Treg cytokine) levels during Zn deficiency, pointing to a malfunctioning of Treg cells and thus imbalance of the immune response ${ }^{(94)}$. As Treg cells are important master regulators within the immune system, essential for tolerance and balance and differentiation of the remaining $\mathrm{CD}^{+} \mathrm{T}$ cell subtypes, a disturbed immune response can be expected.

Treatment of cell cultures with a $\mathrm{Zn}$ chelator disturbed the cytotoxic activity of natural killer cells ${ }^{(95,96)}$. Similar effects were reported for rats fed on a $\mathrm{Zn}$-deficient $\operatorname{diet}^{(97)}$. This effect might decrease the killing of host cells which become infected by the virus.

A number of effects described above are due to the requirement of $\mathrm{Zn}$ for intracellular signal transduction and the consequent disruption of a multitude of signalling pathways when Zn supply is limited. Zn's effect on phosphatases and kinases is central here, as is its ability to induce changes in membrane fluidity and thus receptor expression and dimerization as found in vitro and in vivo ${ }^{(47,59,98)}$. Finally, epigenetic changes occur during $\mathrm{Zn}$ deficiency as described above as found in various models of Zn deficiency ${ }^{(99,100)}$.

In the case of IL- 6 , another connection to Zn deficiency has been described. A SNP was found in the IL- 6 gene at position -174 . It is associated with a disturbed age-related $\mathrm{Zn}$ deficiency, and it seems to be relevant during the regulation of $\mathrm{Zn}$-related genes such as metallothioneins. The frequency of this polymorphism increases with age and offers an additional explanation for 
the high risk of Zn deficiency described for the elderly ${ }^{(46,101)}$. Interestingly, the IL-6-174 SNP was also associated with an increased risk for severe progression of and mortality from COVID-19, as was suggested previously for sepsis, but never proven up to now ${ }^{(102-104)}$. Individuals with this SNP could be actively supplemented with $\mathrm{Zn}$, not only to help prevent severe COVID-19 but also to enable a balanced immune response in general $^{(46,105)}$

Glucocorticoids were suggested as a means to attenuate the cytokine storm and proposed as a treatment option during the hyperinflammatory phase of COVID-19 ${ }^{(72)}$. On the other hand, chronically increased glucocorticoids may augment lymphopenia $^{(106,107)}$. Serum $\mathrm{Zn}$ deficiency was associated with chronically elevated levels of glucocorticoids, especially corticosteroids. However, data are not clear in this regard yet, and studies have been published not recommending the use of glucocorticoids during COVID-19 treatment, or at least recommend caution. Criticism of glucocorticoid use is largely based on data on SARS from 2003, where improper use of systemic corticosteroids increased the risk of osteonecrosis of the femoral head, which is, however, a classical side effect of glucocorticoid therapy and not related to the virus ${ }^{(108-111)}$. At first sight, this is one of the only consequences of $\mathrm{Zn}$ deficiency that might be viewed as an advantage in terms of COVID-19. In this regard, it should also be mentioned that the chronically increased glucocorticoid levels were suggested to be associated with the increased apoptosis of lymphocytes and probably also of cells of the thymus, thus explaining thymic atrophy in mice and humans with decreased serum Zn levels ${ }^{(112-114)}$ However, those suggestions require experimental verification.

The cytokine storm is central to the progression from mild or severe disease to complications and critical illness associated with COVID-19 and should be prevented by any possible means. The hyper-inflammation is largely involved in damaging various organs, including the lung, heart, liver, kidney and probably also the intestine and the brain. Interestingly, the central nervous system, the gastrointestinal tract, lungs, liver, the epidermal, reproductive and skeletal system are clinically affected by severe Zn deficiency which causes elevation of inflammatory markers ${ }^{(16,62)}$. As the treatment of the cytokine storm is complex and the individual patient response to certain treatments is almost impossible to predict, the best option is to prevent the cytokine storm. Thus, groups that are at risk of $\mathrm{Zn}$ deficiency should be supplemented routinely. Of course, individuals with severe pre-existing $\mathrm{Zn}$ deficiency will benefit the most; however, adjusting mild $\mathrm{Zn}$ deficiencies is also of importance especially in individuals from COVID-19 risk groups such as the elderly, diabetic patients and individuals with heart and vascular co-morbidities.

Additional roles of $\mathrm{Zn}$ in the regulation of immune cell function, but perhaps not obviously relevant for what is known of SARS-CoV-2 infection, have been reviewed extensively elsewhere ${ }^{(25,29,44,51,87,96,99,115,116)}$

\section{Zinc deficiency and vascular complications: possible} association with complications affecting multiple organs

Cardiovascular complications are frequently reported during COVID-19, especially in patients with pre-existing pathologies of the heart and vascular system, such as atherosclerosis ${ }^{(79,117)}$.
Venous, arterial and microvascular thromboses are increased in patients with COVID-19. Moreover, COVID-19-associated hypercoagulopathy closely resembles the pathophysiology and phenotype of complement-mediated thrombotic microangiopathy ${ }^{(117)}$. An increase of proinflammatory cytokines, increased complement activation, endothelial dysfunction and immunothrombosis are considered to be key mechanisms of hypercoagulopathy. For instance, venous thromboembolisms, also driven by a hyperinflammatory milieu, were described in $20-31 \%$ of severe COVID-19 cases $^{(37,118-121)}$. Moreover, an increased number of especially polymorphonuclear neutrophils (PMN) together with high amounts of neutrophil extracellular traps were observed in the thrombi of COVID-19 patients ${ }^{(122)}$. Arterial embolism, including acute pulmonary embolism, ischaemic stroke and acute myocardial injury, was also increased in patients with severe SARS-CoV-2 infection ${ }^{(123-126)}$. Subsequent thrombocytopenia was associated with poor prognosis for COVID-19 patients. Concerning the endothelial dysfunction, it was proposed that direct endothelial damage can lead to an increased thrombogenic effect in the microcirculation ${ }^{(127)}$. An impaired microcirculation can cause complications in various organs including the lung, the kidneys, the heart, the brain, the liver or the pancreas.

As already indicated, an increased activation and tissue recruitment of PMN in Zn-deficient individuals are likely ${ }^{(54,128,129)}$. Thus, pre-existing $\mathrm{Zn}$ deficiency may be indirectly associated with thrombus formation. The association of pre-existing Zn deficiency with hyperinflammation was already described in this article and can also be related to an increased risk for thromboembolism. In addition, $\mathrm{Zn}$ is essential for various aspects of physiological coagulation and might impact thrombogenesis as well as fibrinolysis ${ }^{(130,131)}$. However, Zn's effects seem to depend on the microenvironment and might be locally restricted and temporary ${ }^{(130)}$. For example, $\mathrm{Zn}$ can be secreted by activated platelets resulting in locally increased $\mathrm{Zn}$ concentrations in the vicinity of a thrombus, while the systemic $\mathrm{Zn}$ homoeostasis remains probably rather stable. The direct effects of pre-existing $\mathrm{Zn}$ deficiency on coagulation are not entirely clear. Studies in Zn-deficient humans, rodents and guinea pigs revealed clotting abnormalities, impaired platelet function as well as an increased and prolonged bleeding tendency ${ }^{(132,133)}$. Those $Z n$-deficiency-induced defects were reversible by $\mathrm{Zn}$ supplementation ${ }^{(134)}$. In a recent in vitro study, $\mathrm{Zn}$ deficiency inhibited the agonist-activated production of reactive oxygen species (ROS) by platelets and decreased glutathione levels and glutathione peroxidase activity, which might result in altered thrombus formation ${ }^{(135)}$. Due to the lack of detailed and consitent data, a clear conclusion on the effects of $\mathrm{Zn}$ deficiency regarding fibrinolysis and coagulation cannot be drawn. However, as with many topics discussed in this review, a well-balanced $\mathrm{Zn}$ homoeostasis seems to be key to a physiological balance also in the example of coagulation and fibrinolysis.

The risk of developing an acute coronary syndrome during SARS-CoV-2 infection is especially increased in patients with atherosclerotic vascular disease ${ }^{(136)}$. The development and subsequent rupture of vulnerable plaques can result in heart attack or stroke, and subsequent heart failure and death ${ }^{(137,138)}$. During the development of atherosclerosis, up-regulation of adhesion molecules on endothelial cells is one of the central events, largely involving 
the transcription factor NFKB. An increased activation and DNA binding of selected transcription factors during $\mathrm{Zn}$ deficiency were established in vitro ${ }^{(139,140)}$. In addition, the role of $\mathrm{Zn}$ in NFkBrelated signalling has been described in various studies ${ }^{(87,96)}$. The association of severe pre-existing serum $\mathrm{Zn}$ deficiency in mice with an increased risk of atherosclerosis was additionally explained by the $\mathrm{Zn}$-dependent alteration of endothelial surface markers, changes of the plasma lipid composition and the promotion of the proinflammatory milieu ${ }^{(85,96,141)}$. Results from various in vivo and in vitro studies as summarised by Choi et al. indicate that Zn supplementation may reduce the risk of atherosclerosis and protect against myocardial infarction as well as ischaemia/reperfusion injury ${ }^{(23)}$. The vasculitis described in COVID-19 patients resembles the reaction to infections with Varicella zoster virus, where the viral replication in the cerebral arterial wall directly triggered local inflammation $^{(142)}$. Zn supplementation in cell culture experiments was shown to decrease viral replication ${ }^{(143)}$, and Zn supplementation might thus attenuate virus-induced vasculitis. Recently, a molecular modelling study predicted an interaction of $\mathrm{Zn}$ with RNA-dependent, RNA-polymerase and 3C-like proteinase enzymes of SARS-CoV-2, which awaits experimental verification.

Associations of diseases such as arterial hypertension, atherosclerosis, congestive heart failure and CHD are described in both Zn deficiency and COVID-19 $9^{(85,144-150)}$, but a causal link between Zn deficiency and the observations in COVID-19 remains to be established.

\section{Pre-existing zinc deficiency is associated with severe progression of respiratory diseases}

SARS-CoV-2 enters the human body predominantly via the respiratory tract. In healthy individuals, viral entry is hampered by the mucous-coated membrane of the alveoli as well as the immune cells and their anti-viral products protecting the lungs ${ }^{(151)}$. When SARS-CoV-2 has crossed the epithelial barrier, it can elicit extensive alveolar injury and pulmonary fibrosis, which are irreversible pathological changes. The progression of mild COVID-19 to pneumonia, acute lung injury and subsequently to ARDS is the leading cause of mortality, affecting $5-10 \%$ of the COVID-19 patients worldwide ${ }^{(152,153)}$.

As illustrated in Fig. 3, the expression of tight-junction proteins is decreased under $\mathrm{Zn}$-deficient conditions. This as well as reduced expression of adherens junction proteins reduces the integrity of the endothelial barrier and might facilitate viral entry, as shown in a variety of studies investigating human and rodent tissue in vivo, ex vivo and in vitro ${ }^{(54,141,154-157)}$. Experiments using an ex vivo model of differentiated human airway epithelium showed that exposure to Zn-depleted medium significantly augmented the down-regulation of the tight junction proteins such as Zonula Occludens-1 and Claudin-1 that was induced by cigarette smoke extract ${ }^{(154)}$. Another study, which investigated primary human upper airway and type I/II alveolar epithelial cells that were grown in Zn-depleted compared with $\mathrm{Zn}$-adequate medium, revealed that $\mathrm{Zn}$ deprivation augmented activation-induced proteolysis of E-cadherin and $\beta$-catenin, both adherens junction proteins ${ }^{(157)}$. Since intracellular Zn levels of endothelial cells largely depend on the protein-bound $\mathrm{Zn}$ pool in the blood serum, the cells are deprived of $\mathrm{Zn}$ during serum hypozincaemia. Low endothelial $\mathrm{Zn}$ disturbs cellular metabolism and is associated with oxidative stress. Increased serum levels of oxidised LDL and high amounts of inflammatory cytokines derived from activated monocytes are frequently observed in individuals with serum $\mathrm{Zn}$ deficiency, and together with the high oxidative stress, this leads to increased apoptosis of epithelial cells. Consequently, mild preexisting $\mathrm{Zn}$ deficiency combined with inflammation-induced serum hypozincaemia may exacerbate epithelial barrier permeability of the lung in COVID-19 patients.

Previous investigations on SARS-CoV-1 infections revealed that phagocytic cells largely contributed to the antibody-mediated elimination of the virus ${ }^{(158)}$. Amongst the phagocytes, resident macrophages are constantly patrolling the lung, while high numbers of PMN are recruited during infections, abundant ones. PMN are highly reactive cells, equipped with their complete antimicrobial weaponry when they leave the bone marrow. Upon activation, they release their granular content which includes highly reactive mediators such as ROS, reactive nitrogen species, antimicrobial peptides, matrix metalloproteases that degrade extracellular matrix and more ${ }^{(159,160)}$. Those factors are primarily secreted to destroy invading pathogens. However, if secreted in excessively high amounts, they can destroy the host tissue as well ${ }^{(161)}$, as was suggested to explain tissue injury in SARSCoV-2 infections.

With respect to PMN activity, the effects of Zn deficiency are not clearly defined. While some studies describe attenuated motility of PMN in moderately Zn-deficient individuals ${ }^{(162,163)}$, the numbers of PMN found in the infected tissues of animals with pre-existing $\mathrm{Zn}$ deficiency are higher compared with animals with adequate $\mathrm{Zn}$ supply ${ }^{(128,129)}$. Whether the defect in chemotaxis is compensated by the elevated numbers of PMN observed in Zn-deficient rodents, remains to be investigated $^{(49)}$. The formation of ROS and neutrophil extracellular traps by PMN was reported to be decreased in $\mathrm{Zn}$-deficient cells in culture ${ }^{(164)}$. Surprisingly, Zn supplementation of mice in vivo, or of human neutrophils in cell culture, also decreased activation-induced neutrophil extracellular trap formation ${ }^{(54)}$. In this context, we would like to mention that it was shown for various cell types, mostly in cell culture models, that $\mathrm{Zn}$ deficiency alters redox metabolism and results in oxidative stress ${ }^{(165-169)}$. There are several suggestions for the mechanisms responsible for the elevated ROS levels in $\mathrm{Zn}$-deficient conditions, as summarised in Fig. 4. First, Zn deficiency was related to the decreased activity of enzymes which are central to ROS metabolism, such as the $\mathrm{Cu} / \mathrm{Zn}$ superoxide dismutase in vitro. Here, the inactivation of enzymes due to the lack of $\mathrm{Zn}$ in their catalytic centre was described $^{(168,170,171)}$. Second, expression of metallothioneins, not only the major intracellular Zn binding proteins but also an important free radical scavenger, is decreased during $\mathrm{Zn}$ deficiency, which was shown using various models of Zn deficiency and was recently summarised ${ }^{(168)}$. As a third mechanism, $\mathrm{Zn}$ is necessary to protect the free sulfhydryl groups in proteins from oxidation. A lack of Zn might also alter the formation of intramolecular disulphide bonds, causing steric hindrance and conformational changes, which can be associated with increased activity or the loss of function 
Fig. 3 Pulmonary effects observed in Severe Acute Respiratory Syndrome-Coronavirus-2 (SARS-CoV-2) infected patients with pre-existing zinc deficiency as compared with patients with a balanced zinc homoeostasis. Pre-existing zinc deficiency (left) was suggested to increase the number, recruitment and inflammatory potential of especially PMN to the insides of the bronchi. Lymphocyte numbers are generally decreased, most prominently affecting $T^{2}$ helper cell $\left(T_{H}\right)$ cells. The zinc deficiencyrelated decrease in tight junction expression and the increase in endothelial cell apoptosis have several consequences. Thus, infiltration of the lung by host cells, as well as the leakage of pathogens such as SARS-CoV-2 and secondary pathogens such as Streptococcus pneumoniae into the vascular system, is frequently observed during zinc deficiency. Detailed explanations can be found in the text. For comparison, the characteristics of zinc-adequate individual are indicated on the right. Ab, antibody; B, B cell; E, erythrocyte; G-CSF, granulocyte colony-stimulating factor; GC, glucocorticoid; GM-CSF, granulocyte-macrophage CSF; MMP, matrix metalloproteinase; Mo, monocyte; M $\phi$, macrophage; NET, neutrophil extracellular trap; NK, natural killer cell; PI, platelet; PMN, polymorphonuclear neutrophil; ROS, reactive oxygen species; Tc, cytotoxic T cell; TJ, tight junction; ZA, zinc adequate; ZD, zinc deficient.

of molecules involved in balancing the redox state of the cells, determined in cell culture experiments and suggested by in vivo examination of $\mathrm{Zn}$-deficient animals ${ }^{(172)}$. In Zn-adequate conditions, $\mathrm{Zn}$ competes with other redox-active metal ions with similar coordination chemistry such as $\mathrm{Cu}$ or $\mathrm{Fe}$ for protein binding. The lack of $\mathrm{Zn}$ as competitor is a fourth suggested mechanism explaining the increased oxidative stress when $\mathrm{Zn}$ is limited. This was investigated for the oxidation of myoglobin and the activity of superoxide dismutase ${ }^{(170,173)}$. Zn also competes with $\mathrm{Fe}$ and $\mathrm{Cu}$ for binding to the NADPH oxidase and usually inhibits NADPH oxidase activity. Increased NADPH oxidase activity was reported for neuronal cells cultured in the $\mathrm{Zn}$-depleted medium ${ }^{(174)}$. In this context, $\mathrm{Zn}$ can bind NADPH, but not NADH, and thus inhibits NADPH-dependent enzymes in vitro ${ }^{(175,176)}$. Moreover, $\mathrm{Zn}$ interferes with the Fenton reaction in vitro suppressing lipid peroxidation ${ }^{(177,178)}$. As a fifth point, Zn deprivation was associated with dysfunctions of mitochondria and the endoplasmic reticulum. Finally, Zn's effect on gene expression might affect redox metabolism. Zn was shown to be involved in the up-regulation of several transcription factors, and some antioxidant molecules such as glutathione and detoxifying enzymes such as glutathione S-transferase and haemeoxygenase-1 mostly investigated using Zn-deficient cell cultures ${ }^{(176,179)}$. The nuclear factor erythroid 2-related factor 2 can be induced by $Z n$, as was investigated in rats fed on a low-Zn, Zn-adequate or high-Zn $\operatorname{diet}^{(176,179,180)}$. Whether $Z n$ deficiency has the opposite effect to $\mathrm{Zn}$ supplementation remains to be explored, but in summary, the multiple mechanisms described above can explain the overall increase in ROS during Zn deficiency, which was consistently found in various models of $\mathrm{Zn}$ deficiency. We thus hypothesise that in combination with the infection-induced inflammation observed in COVID-19 patients, pre-existing Zn deficiency might augment the formation of ROS and reactive nitrogen species causing severe tissue damage. On the other hand, the anti-oxidative properties of $\mathrm{Zn}$ are widely described and accepted ${ }^{(23,140,181,182)}$, suggesting benefits of $\mathrm{Zn}$ supplementation for COVID-19 patients. 


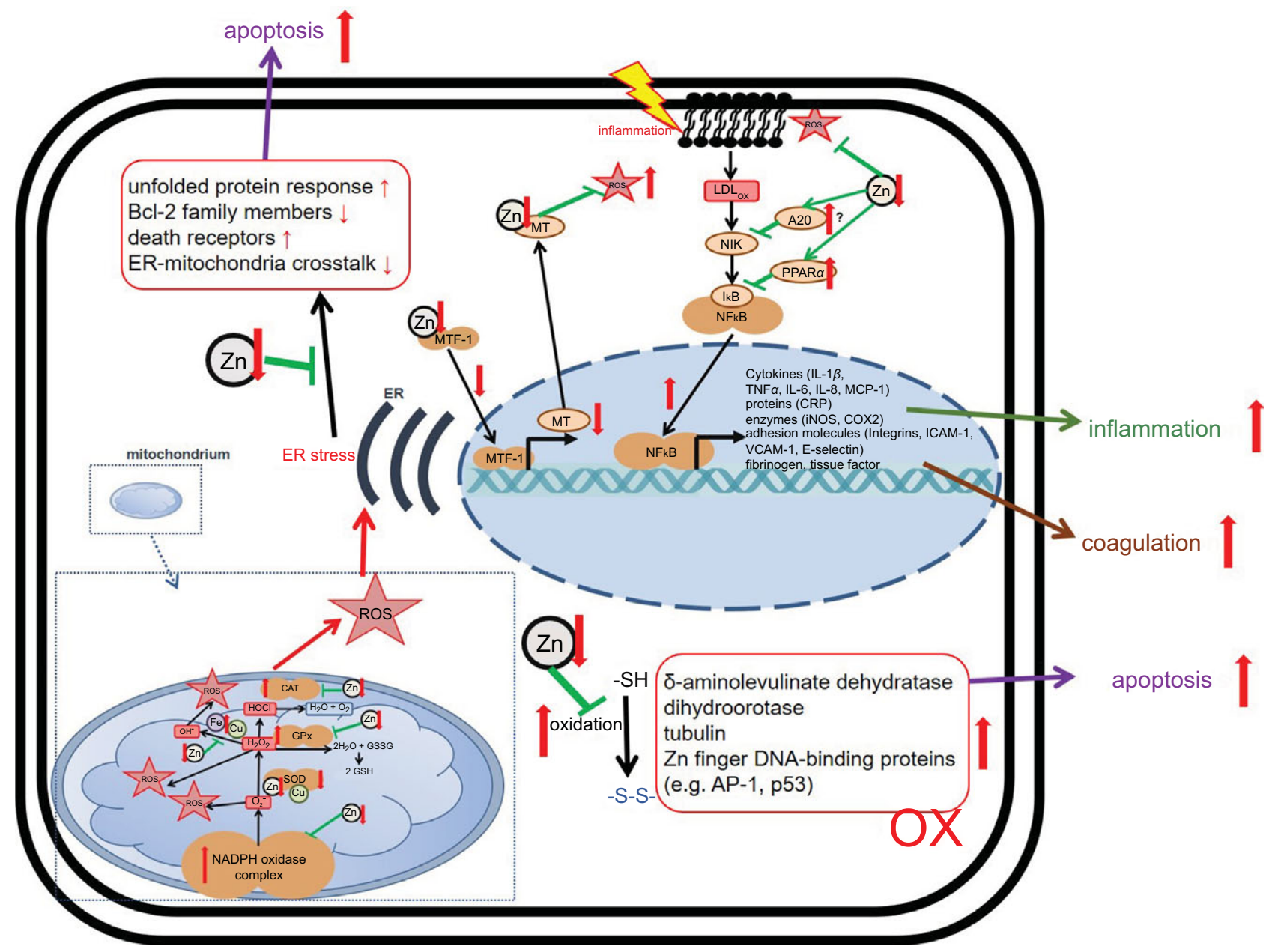

Fig. 4 Effects of zinc deficiency on stress-induced changes in redox metabolism. Green arrows indicate zinc-dependent cellular functions. Red arrows illustrate the effects of zinc deficiency. A detailed description of the mechanisms underlying disturbed redox metabolism during zinc deficiency can be found in the text. AP-1, Activator protein 1; Bcl-2, B-cell lymphoma 2; CAT, catalase; COX, Cyclo-oxygenase; CRP, C-reactive protein; ER, endoplasmic reticulum; GPx, glutathione peroxidase; ICAM, intercellular adhesion molecule-1; iNOS, inducible nitric oxide synthase; MT, metallothionein; MTF, metal-responsive transcription factor-1; Ox, oxidated; MCP, monocyte chemoattractant protein; NIK, NFkB-Inducing Kinase; ROS, reactive oxygen species; SOD, superoxide dismutase; VCAM, vascular cell adhesion molecule.

COVID-19 often shows systemic effects in the patient's tissues and organs, often resulting in multi-organ failure and high death rates ${ }^{(3,74,82,183)}$. Furthermore, 'septic shock' is another cause of mortality from SARS-CoV-2 and is currently observed in 4-8\% of COVID-19 patients ${ }^{(52,53,184)}$. When reading all the articles on COVID-19 discussing the symptoms in individuals undergoing mild compared with severe viral disease, one cannot help but notice the parallels to mild bacterial infections compared with bacterial sepsis and its progression to $\operatorname{ARDS}^{(37,161,185)}$. Regarding bacterial sepsis, various studies in animals and humans describe an association of disease progression and mortality in relation to the $\mathrm{Zn}$ status, which could be extrapolated to COVID-19. It was shown that pre-existing Zn deficiency was a prerequisite for the progression from mild inflammation to pneumonia and severe sepsis in mice. Severity of disease was monitored by analysing the serum levels of proinflammatory cytokines (i.e. assessment of the cytokine storm) and damage to the lungs, the liver and the kidney. Also, serum Zn concentrations were inversely correlated with sepsis severity. Thus, serum $\mathrm{Zn}$ was suggested as a prognostic marker for mortality in septic mice, pigs, adult humans and infants. In critically ill children, complications of sepsis, the necessity for mechanical ventilation and resulting mortality rates were correlated with low serum $\mathrm{Zn}$ levels. ${ }^{(101,128,129,186-193)}$. Moreover, Boudreault et al. revealed that pre-existing $\mathrm{Zn}$ deficiency primes the lungs for severe complications derived from mechanical ventilation, including the progression from acute lung injury to ARDS ${ }^{(194)}$. In cystic fibrosis, Zn deficiency, caused by a splice switch in the Zn Importer ZIP2, caused hypersecretion of the glycoprotein mucin in airway epithelial cells, significantly increasing disease severity ${ }^{(195)}$. Preexisting serum $\mathrm{Zn}$ deficiency was implicated to be responsible for the high incidence of pneumonia in elderly, hospitalised patients ${ }^{(192,196,197)}$. Enhanced infection and virulence of Streptococcus pneumoniae in Zn-deficient mice were reported. In addition to disrupted epithelial barriers and inadequate immune response, the enhanced virulence was explained by the sensitivity of $S$. pneumonia to $\mathrm{Zn}$ intoxication, reduced during Zn deficiency ${ }^{(189)}$. Direct effects of Zn deficiency on viral replication have not been addressed to date. Finally, the correlation between $\mathrm{Zn}$ deficiency and infection severity may be due to 
reverse causality, that is, the negative effects that inflammation has on serum $\mathrm{Zn}$ concentration. We thus suggest that when the serum $\mathrm{Zn}$ levels fall below a certain threshold, the inflammatory response will be self-perpetuating. Again, most tissue damage and detrimental consequences can be expected for patients with pre-existing severe $\mathrm{Zn}$ deficiency, but in view of the manifold effects of already mild deficiency, normalising the Zn status offers an easy and cost-efficient approach to reduce disease symptoms.

The hypothesis that $\mathrm{Zn}$ deficiency is a risk factor for severe COVID-19 progression and the development of pneumonia and ARDS is supported by successful supplementation studies using $\mathrm{Zn}$ to prevent or attenuate respiratory diseases, as we summarised previously ${ }^{(6)}$. Moreover, first data indicating the congruency of low-Zn status of COVID-19 patients as well as the inverse correlation between serum Zn levels and COVID-19 severity were recently published ${ }^{(10,198)}$. However, the low serum $\mathrm{Zn}$ levels might, once more, be the result of the severe inflammatory response elicited by the virus ${ }^{(18)}$. Clear data on possible preexisting serum $\mathrm{Zn}$ defiicencies are still lacking.

\section{Disrupted epithelial barrier integrity during zinc deficiency: opening the way for Severe Acute Respiratory Syndrome-Coronavirus- 2 and co-infections}

Evidence is accumulating that, in addition to attacking the lungs and the respiratory tract, SARS-CoV-2 frequently damages other organs (heart, vessels, nerves/brain, kidneys and skin). Disruption of tissue barriers is an integral part of the pathophysiology of infectious diseases, as it facilitates distribution of the pathogen within the body ${ }^{(151)}$. The effects of $\mathrm{Zn}$ deficiency, described above regarding the lung endothelial barrier, were similarly described for other endothelial layers, including those of kidney, liver, intestine and brain.

It should also be mentioned that the expression of ACE2, lately also called 'SARS-CoV-2 receptor', is not limited to the lungs, that is, the goblet and ciliated epithelial cells of the upper airways, alveolar (Type II) epithelial cells and cells of the pulmonary vasculature. ACE2 is also expressed on migratory angiogenic cells, and vascular smooth muscle cells, cardiofibroblasts, cardiomyocytes, pericytes and epicardial adipose cells of the heart; glomerular endothelial cells, podocytes and proximal tubule epithelial cells of the kidneys; cholangiocytes and hepatocytes of the liver; pigmented epithelial cells, rod and cone photoreceptor cells and Müller glial cells of the retina; enterocytes of the intestines and on cells from circumventricular organs of the central nervous system. Binding of SARS-CoV-2 was claimed to result in the loss of ACE2 from the cell surface due to receptor endocytosis and proteolytic cleavage $^{(199)}$. On the other hand, ADAM17-mediated ACE2 shedding facilitates SARS-CoV-1 entry and induces tissue damage by TNF- $\alpha$ production, which remains to be shown for SARS$\mathrm{COV}-2^{(200)}$. However, disturbed ACE2 expression levels on the cell surface and increased viral entry result from both scenarios. Amongst the normal physiological functions of the ACE2 system are protection against heart failure, myocardial infarction and hypertension. This can explain heart-related COVID-19 complications. Furthermore, defects in the ACE2 system were associated with lung disease, diabetes mellitus and gut dysfunction $^{(199)}$. ACE2 is a Zn-metalloenzyme, and its normal function is therefore $\mathrm{Zn}$-dependent. Thus, a likely explanation for the association of pre-existing Zn deficiency with COVID-19 complications is the decreased ACE2 activity reported for animals fed on a low-Zn diet ${ }^{(201,202)}$. ACE activity was even suggested as a biomarker for moderate $\mathrm{Zn}$ deficiency in patients with idiopathic taste impairment ${ }^{(203)}$. A Zn deficiency-related, mildly restricted ACE2 activity might not result in clinical symptoms. However, if ACE2 activity is further impaired by the virus, it might fall below a certain threshold and cause vascular complications, heart problems, gut disturbances and so on. Conversely, one study reported increased ACE2 activity in the lung tissue of $\mathrm{Zn}$-deficient rats ${ }^{(204)}$. Thus, further clarification is needed before conclusions can be drawn regarding the relation to COVID-19. As $\mathrm{Zn}$ is a structural element of ACE2, the receptor's conformation and subsequent affinity for the virus might be altered in patients with pre-existing $\mathrm{Zn}$ deficiency, which remains to be tested ${ }^{(201)}$. Furthermore, Zn deficiency might impair ACE2 expression, as was reported for other Zn-containing metalloenzymes ${ }^{(182)}$. Zn supplementation led to decreased Sirtuin-1 activity as found in cell culture. Interestingly, $\mathrm{Zn}$ removal from the closely related Plasmodium falciparum Sirtuin-2 deacetylase, resulted in structural collapse and malfunction of the enzyme. Since Sirtuin-1 is involved in regulating ACE2 transcription, this might result in disturbed ACE2 expression in patients with a Zn imbalance ${ }^{(100,205,206)}$.

In summary, pre-existing $\mathrm{Zn}$ deficiency might alter ACE2 expression, structure and/or activity in a tissue-specific manner, which could affect viral entry and pre-dispose to virus-induced tissue damage, but more and detailed studies are necessary to verify those speculation.

Acute kidney injury is another complication that can cause high mortality in COVID-19 patients ${ }^{(207)}$. The total incidence of acute kidney injury in COVID-19 patients is estimated to be about 4-9\%, while in a retrospective study, it was demonstrated that the percentage of patients with complications can reach $37-78 \%(207,208)$. In addition to increased epithelial barrier permeability and the infection with the virus via ACE2, Zn deficiency was associated with renal insufficiency ${ }^{(85)}$. Although described for rats, severe $\mathrm{Zn}$ deficiency that was observed in parallel decreased the glomerular filtration rates and renal blood flow, while renal vascular resistance increased $^{(209)}$. The resulting renal insufficiency might be a prerequisite for acute kidney injury and kidney failure during COVID-19. This hypothesis is supported by the finding that the role of $\mathrm{Zn}$ in renal function seems to be more crucial in diseased animals than in healthy ones. Tubulointerstitial nephropathy and glomerular haemodynamics were, for example, aggravated in rats with preexisting $\mathrm{Zn}$ deficiency that were suffering from unilateral ureteral obstruction. Zn deficiency further increased the disease-related high expression of endothelin-1 in the glomeruli of the obstructed kidneys ${ }^{(210,211)}$. Since during kidney diseases and dialysis, $\mathrm{Zn}$ loss is increased, Zn deficiency is self-perpetuating and a vicious circle develops causing more severe disease ${ }^{(212)}$.

Diarrhoea was reported as a consequence of COVID-19 in a high number of cases ${ }^{(77)}$. The association of $\mathrm{Zn}$ deficiency with intestinal alterations and a leaky gut are well described in clinical 
investigations and $\mathrm{Zn}$ supplementation studies, and there are excellent reviews focusing on the underlying mechanism ${ }^{(213-215)}$.

Infection routes of COVID-19 may not include the intestinal tract. However, the leaky gut increases the risk of secondary infections, and intestinal morbidities as commensals are able to enter the human body ${ }^{(216,217)}$, especially if the immune system is otherwise occupied by the response to SARS-CoV-2. During renal diseases, nutrients not only $\mathrm{Zn}$ but also other elements important for an effective immune response can be lost from the body together with fluids. Consequently, dehydration and deficiency of various minerals can be expected ${ }^{(213,218)}$.

Finally, it is not without reason that $\mathrm{Zn}$ supplementation, especially of children in developing countries, is recommended by the WHO to prevent and treat diarrhoea, underlining the relevance of $\mathrm{Zn}$ for preserving a healthy gut, as a basic step towards improving the overall health status of individuals ${ }^{(219)}$.

\section{Pre-existing $\mathrm{Zn}$ deficiency decreases wound healing and tissue regeneration}

Long-term consequences of COVID-19 including the damage to multiple organs are becoming more and more apparent. This is of course partly due to the severe damage caused by the virus but also due to slow and inefficient recovery and healing. Again, there are striking parallels between COVID-19 symptoms and impaired healing observed in Zn deficiency ${ }^{(220,221)}$, as found during ex vivo investigation of differentiated human airway epithelium and described by several research groups ${ }^{(150,154)}$.

In $\mathrm{Zn}$-deficient rats, intestinal cell proliferation and the quality of intestinal wound healing after intestinal surgery were decreased compared with Zn-adequate controls. This was explained by higher expression of matrix metalloproteinases 2, 9 and 13 and decreased expression of Ki67 (proliferation marker). In addition, the collagen type I:III ratio was reduced in the $\mathrm{Zn}$-deficient animals ${ }^{(222)}$. Whereas collagen type III dominates the early phase of wound healing, collagen type I rather represents late phase wound healing.

When the influx of $\mathrm{Zn}$ into the liver after partial hepatectomy was inhibited in a knock-out mutant of the Zn importer Zip14 in mice, proliferation of hepatocytes was significantly decreased ${ }^{(223)}$. Pre-existing Zn deficiency had similar effects regarding regeneration of heart and lungs. Moreover, Zn supplementation improved the recovery from ischaemia as for example shown in rats where $\mathrm{Zn}$ was added during re-perfusion or to the $\operatorname{diet}^{(154,224,225)}$.

A $\mathrm{Zn}$-adequate nutrition may thus also be relevant during recovery from COVID-19.

\section{Zinc deficiency as pre-requisite to virus-induced neuronal damage and loss in smell and taste}

In healthy and $\mathrm{Zn}$-adequate individuals, the brain is usually separated from most of the immune cells by the blood-brain barrier. If the blood-brain barrier is damaged, for example, due to high levels of matrix metalloproteinase-9 or other matrix-degrading factors, the brain can easily be infiltrated by immune cells as well as by pathogens, causing neuronal damage ${ }^{(226)}$. Thus, entry of a virus into the brain and subsequent damage of the neuronal system culminating in disturbances of their sensory function might be expected during severe $\mathrm{Zn}$ deficiency.

Neurological complications of COVID-19 include meningitis and encephalitis, followed by delirium and coma, acute disseminated encephalomyelitis, myelitis, Guillain-Barré syndrome and cerebrovascular complications (stroke, transient ischaemic attack, central nervous system vasculitis) ${ }^{(227)}$. However, in comparison with patients with respiratory complications, the proportion of patients with neurological manifestations of COVID-19 might be rather small. Since a high percentage of the world's population is likely to be infected with the virus, the total number of patients with neuronal complication might be expected to be high. Moreover, lifelong disabilities can result from encephalitis and stroke. Psychosis and paralysis are also discussed as COVID-19-related $^{(227,228)}$. Subsequent health, social, care and economic costs to society will be high ${ }^{(227,228)}$. Although the exact mechanisms underlying the neurological disturbances in COVID-19 patients are so far not clearly defined, a combination of direct viral invasion with secondary effects of the overresponding immune system is likely.

Serum $\mathrm{Zn}$ deficiency has been related to neuronal conditions such as autism, depression, psychosis, Alzheimer's disease, stroke and schizophrenia. Disturbed neurogenesis and elevated apoptosis of neuronal cells, which can result in defects in learning and memory, were described during $\mathrm{Zn}$ deficiency, as was shown in animals fed on a Zn-deficient diet. Retrospective studies on stroke patients also suggest a clinical significance for serum $\mathrm{Zn}$ deficiency ${ }^{(229-235)}$. The increase in neuronal apoptosis might involve mitochondrial p53 as well as p53-dependent caspase-mediated mechanisms as shown in vitro ${ }^{(236)}$. Moreover, a deficiency in synaptic $\mathrm{Zn}$, achieved by $\mathrm{Zn}$ chelation, elevated the susceptibility to epileptic seizures in rodents $^{(237,238)}$. Also, $\mathrm{Zn}$ deficiency reduces the amount of $\mathrm{Zn}$ available for signal transmission and processing of information, considering that $\mathrm{Zn}$ functions as a neurotransmitter, as reviewed in detail elsewhere ${ }^{(239)}$. $\mathrm{Zn}$ is usually packaged into synaptic vesicles of a large sub-population of excitatory neurons for the purpose of neurotransmission. In addition, Zn functions as an important neuromodulator in the olfactory bulbs in rodents ${ }^{(240,241)}$. Restricting the release of $Z n$ by knocking out the Zn exporter ZnT3 inhibited cell proliferation and neuronal differentiation in the adult hippocampus in mice ${ }^{(242)}$. Surprisingly, $\mathrm{Zn}$ in the brain remains unaltered or might even be elevated and involved in Alzheimer-related plaque formation in $\mathrm{Zn}$-deficient animals and humans ${ }^{(243-245)}$. Thus, the relevance of direct effects of $\mathrm{Zn}$ deficiency to explain neuronal damage and defects in brain function awaits further data to assist verification. However, ROS, reactive nitrogen species and matrix metalloproteinase-9, which can cross the blood-brain barrier, are elevated during Zn deficiency and affect blood-brain barrier integrity, thus explaining the neuronal damage that has been found in vitro and in vivo ${ }^{(246,247)}$.

Although not in itself life threatening, descriptions of disturbed sense of smell or taste, or both, in COVID-19 patients have accumulated ${ }^{(248-251)}$. An association between $\mathrm{Zn}$ deficiency and the (partial) loss of smell, taste or both has been described in several studies ${ }^{(252,253)}$. However, underlying mechanisms are so far not clear. Thus, a connection between $\mathrm{Zn}$ deficiency and the disturbances in taste and smell in COVID-19 patients must be carefully analysed in future studies. Extrapolating from the literature, however, still suggests some logical associations. 


\section{The elderly: a risk group not only for $\mathrm{Zn}$ deficiency}

The above-discussed consequences of $\mathrm{Zn}$ deficiency are relevant for all age groups. However, in a large number of subjects older than 65 years, co-morbidities may exist. Thus, the association of the age-related decline of serum $\mathrm{Zn}$ with the high susceptibility of the elderly for severe COVID-19 is hard to estimate. Instead, we would like to point out that although this article's focus is $\mathrm{Zn}$, a deficiency in other nutritional elements could also worsen COVID-19 prognosis ${ }^{(3,254,255)}$. Especially, the elderly suffer not only from Zn deficiency but often from inadequate nutrition. Thus, their nutritional status should generally be checked regularly. It was estimated that the prevalence of inappropriate nutrition risk in Europe is $8.5 \%$ in the community setting, $17.5 \%$ in residential care and $28 \%$ in hospitalisation for individuals $\geq 65$ years $^{(256)}$. The evidence of the relationship between inappropriate nutrition, immunosenescence and the higher morbidity and mortality from COVID-19 in elderly patients was recently discussed ${ }^{(3,254)}$. Those articles may be consulted in regard to options especially for supporting the aged population in addition to $\mathrm{Zn}$ supplementation. The articles provide an elaboration on the impact of malnutrition on the immune system specifically of older subjects including cell-mediated immunity, cytokine production and phagocytic function ${ }^{(3,6,7,254)}$.

However, we believe that $\mathrm{Zn}$ supplementation of groups at risk of Zn deficiency and especially in case of the elderly can significantly reduce the severity of infectious diseases such as COVID-19, especially when combined with a generally optimised and nutritious diet, and physical exercise ${ }^{(6,7,254)}$.

\section{Next step: clinical trials}

Based on the available literature, this article suggests a multitude of mechanisms as to how pre-existing $\mathrm{Zn}$ deficiency poses a risk of higher susceptibility to SARS-CoV-2 infections and a more severe progression of disease. To test this hypothesis, clinical studies are necessary and some are already registered ${ }^{(257)}$ (online Supplementary Table S1). Moreover, first clinical data support the hypothesis that serum Zn levels are decreased in COVID-19 patients and that disease severity and mortality might be inversely correlated with serum $\mathrm{Zn}$ concentration ${ }^{(10,258)}$. A decreased serum $\mathrm{Zn}$ level might perhaps be expected in COVID-19 patients due to the strong inflammatory response. Indeed, in serum samples from thirty-five patients with COVID-19, Zn levels were below those from healthy controls ${ }^{(10)}$. Furthermore, in a study of pregnant women, COVID-19 was associated with lower serum Zn levels and serum Zn was negatively correlated with inflammatory markers ${ }^{(259)}$. Thus, subjects starting out with an inherent Zn deficiency might be expected to be less well prepared for a COVID-19-induced decrease in serum $\mathrm{Zn}$. In this regard, serum samples from non-survivors of COVID-19, taken at various time points, showed that the majority were below the threshold categorised as Zn-deficient. This was also noted for half of the surviving patients. The same study also found a Se deficiency in the majority of patients. The levels of Selenoprotein $\mathrm{P}$ and $\mathrm{Zn}$ in relation to the age of the subject were identified as reliable prognostic indicators for COVID-19 survival ${ }^{(10)}$. Analysis and correction of Se and $\mathrm{Zn}$ status were recommended. Another study also found that a significant number of COVID-19 patients were $\mathrm{Zn}$ deficient. Here, $\mathrm{Zn}$-deficient patients revealed more complications, a prolonged hospital stay and higher mortality ${ }^{(258)}$. Low Zn levels in COVID-19 patients at clinical admission were associated with poor disease outcomes ${ }^{(198)}$. Finally, in Sakai City Medical Center (Osaka, Japan), most severely ill patients with COVID-19 showed Zn deficiency. Regarding those patients, critical illness could be predicted by serum $\mathrm{Zn}$ values. The authors thus suggest serum Zn levels as a predictive factor for a critical illness of COVID-19(260). Additional studies on correlating serum $\mathrm{Zn}$ levels with disease severity are ongoing ${ }^{(261)}$.

The data we present strongly suggest that individuals with severe pre-existing $Z n$ deficiency should be included in potential risk groups for COVID-19. We also suggest that prophylactic Zn supplementation, addressing mild pre-existing $\mathrm{Zn}$ deficiency, would be more promising than using $\mathrm{Zn}$ for the treatment of active disease. In several registered studies, $Z n$ supplementation of groups with high risk of close contact with SARS-CoV-2, including medical or military personnel, is being investigated. Finally, the use of $\mathrm{Zn}$ supplementation alone or in combination with other treatment strategies is being tested in clinical studies. First data on the benefits of $\mathrm{Zn}$ supplementation as monitored by improved disease status in four confirmed cases of COVID-19 which were supplemented with up to $200 \mathrm{mg}$ of elemental $\mathrm{Zn}$ per $d$ were recently published ${ }^{(262)}$. However, only a minimal effect of $\mathrm{Zn}$ on the survival of $\mathrm{Zn}$ treated $(100 \mathrm{mg}$ elemental Zn per day) $v$. untreated COVID-19 patients was found by others ${ }^{(263)}$. Supplementation studies using $\mathrm{Zn}$ together with the ionophore chloroquine have so far produced contradictory results ${ }^{(264-268)}$.

Combining the Zn-related data from descriptive, preventive and treatment studies will be necessary to increase our knowledge of the importance of $\mathrm{Zn}$ homoeostasis during COVID-19 infections and for developing optimal Zn-based supplementation strategies.

\section{Conclusion}

$\mathrm{Zn}$ is not without reason called an 'essential' trace element. Although its single actions on the various cells of the human body might be small and the symptoms of mild to moderate $\mathrm{Zn}$ deficiency are rather subtle, the pre-existing lack of $\mathrm{Zn}$ in combination with a pathogen such as SARS-CoV-2 can be detrimental and life threatening. Unfortunately, the current data for COVID-19 patients do not allow to distinguish, whether the low serum $\mathrm{Zn}$ levels repeatedly found are elicited by virusinduced inflammation, or are reflecting a pre-existing Zn deficiency which cause a more severe disease. Irrespective of this ambiguity, it is quite obvious that groups at risk of Zn deficiency may also be at risk of severe progression of COVID-19, in which the literature on the effects of Zn deficiency, summarised in this article, emphasises. Still, this hypothesis needs to be tested experimentally in clinical studies, some of which are currently in progress. At present, the hypothesis is only supported by data derived largely from animal and cell culture models of $\mathrm{Zn}$ deficiency.

This article underlines the various ways as to how a vicious circle of pre-existing, low-grade $\mathrm{Zn}$ deficiency and mild 
pathogen-induced symptoms, followed by increased loss of $\mathrm{Zn}$ from the body and the switch to more severe symptoms and serious complications, can be generated. Especially since $\mathrm{Zn}$ and its deficiency can have a wide variety of individually very different effects, the consequences of pre-existing Zn deficiency in combination with a pathogen like SARS-CoV-2 that causes so many different symptoms and complications by itself are almost impossible to predict. However, as a conclusion, it can be assumed that Zn deficiency represents a risk for severe progression of SARS$\mathrm{CoV}-2$-induced disease and a high mortality therefrom. As $\mathrm{Zn}$ supplementation is cost-effective and can be regarded as safe, it is highly recommended to supplement individuals who are at risk of Zn deficiency. Finally, we would like to add that more attention should be paid to monitoring nutritional status, since minerals and trace elements are inevitably associated with an efficient immune response. Collaborations between the wide range of clinical and research expertise from the nutritional field along with those involved in intensive care treatment, forming a COVID-19 Nutrition Network is desirable.

\section{Acknowledgements}

We thank Wenlei Liu for great support in designing the Figures and the Table. L. Rink is a member of Zinc-Net.

This research received no specific grant from any funding agency, commercial or not-for-profit sectors.

I. W., B. R. and L. R. drafted the original manuscript and figures. A. J. S. edited language and style and contributed substantially to the revised manuscript. All authors supported writing the manuscript and designing figures and table. The manuscript, figures and the table were critically proofread by all authors.

The authors declare that there are no conflicts of interest.

\section{Supplementary material}

For supplementary material referred to in this article, please visit https://doi.org/10.1017/S0007114521000738

\section{References}

1. World Health Organization (2020) WHO Director-General's opening remarks at the media briefing on COVID-19-11 March 2020. https://www.who.int/dg/speeches/detail/whodirector-general-s-opening-remarks-at-the-media-briefingon-covid-19\%2D\%2D-11-march-2020 (accessed July 2020).

2. World Health Organization (2020) Clinical Management of COVID-19 Interim Guidance 27 May 2020, 2019th ed. Geneva: WHO.

3. Bencivenga L, Rengo G \& Varricchi G (2020) Elderly at time of Coronavirus disease 2019 (COVID-19): possible role of immunosenescence and malnutrition. Geroscience 42, 1089-1092.

4. World Health Organization (2020) Malnutrition. https://www. who.int/news-room/fact-sheets/detail/malnutrition (accessed July 2020).

5. Rios-Lugo MJ, Madrigal-Arellano C, Gaytán-Hernández D, et al. (2020) Association of serum zinc levels in overweight and obesity. Biol Trace Elem Res 198, 51-57.
6. Wessels I, Rolles B \& Rink L (2020) The potential impact of zinc supplementation on COVID-19 pathogenesis. Front Immunol 11, 1712

7. Skalny AV, Rink L, Ajsuvakova OP, et al. (2020) Zinc and respiratory tract infections: perspectives for COVID19 (Review). Int J Mol Med 46, 17-26.

8. Sandstead HH \& Freeland-Graves JH (2014) Dietary phytate, zinc and hidden zinc deficiency. J Trace Elem Med Biol 28, 414-417

9. Lowe NM, Fekete K \& Decsi T (2009) Methods of assessment of zinc status in humans: a systematic review. Am J Clin Nutr 89, 2040S-2051S.

10. Heller RA, Sun Q, Hackler J, et al. (2020) Prediction of survival odds in COVID-19 by zinc, age and selenoprotein $\mathrm{P}$ as composite biomarker. Redox Biol 38, 101764.

11. Guillard O, Piriou A, Gombert J, et al. (1979) Diurnal variations of zinc, copper and magnesium in the serum of normal fasting adults. Biomedicine 31, 193-194.

12. King LE, Frentzel JW, Mann JJ, et al. (2005) Chronic zinc deficiency in mice disrupted $\mathrm{T}$ cell lymphopoiesis and erythropoiesis while B cell lymphopoiesis and myelopoiesis were maintained. J Am Coll Nutr 24, 494-502.

13. King LE \& Fraker PJ (2002) Zinc deficiency in mice alters myelopoiesis and hematopoiesis. J Nutr 132, 3301-3307.

14. Beck FW, Prasad AS, Kaplan J, et al. (1997) Changes in cytokine production and $\mathrm{T}$ cell subpopulations in experimentally induced zinc-deficient humans. Am J Physiol 272, E1002E1007.

15. Trame S, Wessels I, Haase H, et al. (2018) A short 18 items food frequency questionnaire biochemically validated to estimate zinc status in humans. J Trace Elem Med Biol 49, 285-295.

16. Prasad AS (2020) Lessons learned from experimental human model of zinc deficiency. J Immunol Res 2020, 9207279.

17. King JC, Brown KH, Gibson RS, et al. (2015) Biomarkers of nutrition for development (BOND)-Zinc review. J Nutr $\mathbf{1 4 6}$, 858S-885S.

18. McDonald CM, Suchdev PS, Krebs NF, et al. (2020) Adjusting plasma or serum zinc concentrations for inflammation: biomarkers Reflecting Inflammation and Nutritional Determinants of Anemia (BRINDA) project. Am J Clin Nutr 111, 927-937.

19. Likoswe BH, Phiri FP, Broadley MR, et al. (2020) Inflammation adjustment by two methods decreases the estimated prevalence of zinc deficiency in Malawi. Nutrients 12, 6.

20. Sandstead HH (2012) Subclinical zinc deficiency impairs human brain function. J Trace Elem Med Biol 26, 70-73.

21. Prasad AS (1985) Clinical and biochemical manifestation zinc deficiency in human subjects. J Pharmacol 16, 344-352.

22. Ackland ML \& Michalczyk A (2006) Zinc deficiency and its inherited disorders: a review. Genes Nutr 1, 41-49.

23. Choi S, Liu X \& Pan Z (2018) Zinc deficiency and cellular oxidative stress: prognostic implications in cardiovascular diseases. Acta Pharmacol Sin 39, 1120-1132.

24. Hambidge KM \& Krebs NF (2007) Zinc deficiency: a special challenge. J Nutr 137, 1101-1105.

25. Wessels I \& Rink L (2020) Micronutrients in autoimmune diseases: possible therapeutic benefits of zinc and vitamin D. J Nutr Biochem 77, 108240.

26. Barnes PM \& Moynahan EJ (1973) Zinc deficiency in acrodermatitis enteropathica: multiple dietary intolerance treated with synthetic diet. Proc R Soc Med 66, 327-329.

27. Kahmann L, Uciechowski P, Warmuth S, et al. (2008) Zinc supplementation in the elderly reduces spontaneous inflammatory cytokine release and restores $\mathrm{T}$ cell functions. Rejuvenation Res 11, 227-237. 
28. Roohani N, Hurrell R, Kelishadi R, et al. (2013) Zinc and its importance for human health: an integrative review. $J$ Res Med Sci 18, 144-157.

29. Beyersmann D \& Haase H (2001) Functions of zinc in signaling, proliferation and differentiation of mammalian cells. Biometals 14, 331-341.

30. Truong-Tran AQ, Carter J, Ruffin RE, et al. (2001) The role of zinc in caspase activation and apoptotic cell death. Biometals 14, 315-330.

31. Leon O \& Roth M (2000) Zinc fingers: DNA binding and protein-protein interactions. Biol Res 33, 21-30.

32. Yamasaki S, Sakata-Sogawa K, Hasegawa A, et al. (2007) Zinc is a novel intracellular second messenger. J Cell Biol 177, 637-645.

33. Tóth K (2011) Zinc in neurotransmission. Annu Rev Nutr 31 , 139-153.

34. Caulfield LE, Onis M de, Blössner M, et al. (2004) Undernutrition as an underlying cause of child deaths associated with diarrhea, pneumonia, malaria, and measles. $A m J$ Clin Nutr 80, 193-198.

35. Fischer Walker CL, Ezzati M \& Black RE (2009) Global and regional child mortality and burden of disease attributable to zinc deficiency. Eur J Clin Nutr 63, 591-597.

36. Diao b, Wang c, Tan y, et al. (2020) reduction and functional exhaustion of $\mathrm{t}$ cells in patients with Coronavirus disease 2019 (COVID-19). Front Immunol 11, 1-7.

37. Liu X, Zhang R \& He G (2020) Hematological findings in coronavirus disease 2019: indications of progression of disease. Ann Hematol 99, 1421-1428.

38. Liu J, Li S, Liu J, et al. (2020) Longitudinal characteristics of lymphocyte responses and cytokine profiles in the peripheral blood of SARS-CoV-2 infected patients. EBioMedicine 55, 102763.

39. Ganji A, Farahani I, Khansarinejad B, et al. (2020) Increased expression of CD8 marker on T-cells in COVID-19 patients. Blood Cells Mol Dis 83, 102437.

40. Jiang M, Guo Y, Luo Q, et al. (2020) T-Cell subset counts in peripheral blood can be used as discriminatory biomarkers for diagnosis and severity prediction of coronavirus disease 2019. J Infect Dis 222, 198-202.

41. Xu Z, Shi L, Wang Y, et al. (2020) Pathological findings of COVID-19 associated with acute respiratory distress syndrome. Lancet Respir Med 8, 420-422.

42. Prasad AS, Rabbani P, Abbasii A, et al. (1978) Experimental zinc deficiency in humans. Ann Intern Med 89, 483-490.

43. Iwata T, Incefy GS, Tanaka T, et al. (1979) Circulating thymic hormone levels in zinc deficiency. Cell Immunol 47, 100-105.

44. Hönscheid A, Rink L \& Haase H (2009) T-lymphocytes: a target for stimulatory and inhibitory effects of zinc ions. Endocr Metab Immune Disord Drug Targets 9, 132-144.

45. King LE, Osati-Ashtiani F \& Fraker PJ (2002) Apoptosis plays a distinct role in the loss of precursor lymphocytes during zinc deficiency in mice. J Nutr 132, 974-979.

46. Mocchegiani E, Giacconi R, Costarelli L, et al. (2008) Zinc deficiency and IL-6 -174G/C polymorphism in old people from different European countries: effect of zinc supplementation. ZINCAGE study. Exp Gerontol 43, 433-444.

47. Kaltenberg J, Plum LM, Ober-Blöbaum JL, et al. (2010) Zinc signals promote IL-2-dependent proliferation of T cells. Eur J Immunol 40, 1496-1503.

48. Anzilotti C, Swan DJ, Boisson B, et al. (2019) An essential role for the $\mathrm{Zn} 2+$ transporter ZIP7 in B cell development. Nat Immunol 20, 350-361.

49. Fraker PJ \& King LE (2004) Reprogramming of the immune system during zinc deficiency. Annu Rev Nutr 24, 277-298.

50. Nurmatov U, Nwaru BI, Devereux G, et al. (2012) Confounding and effect modification in studies of diet and childhood asthma and allergies. Allergy 67, 1041-1059.
51. Kulik L, Maywald M, Kloubert V, et al. (2019) Zinc deficiency drives Th17 polarization and promotes loss of Treg cell function. J Nutr Biochem 63, 11-18.

52. Huang C, Wang Y, Li X, et al. (2020) Clinical features of patients infected with 2019 novel coronavirus in Wuhan, China. Lancet 395, 497-506.

53. Wang D, Hu B, Hu C, et al. (2020) Clinical Characteristics of 138 Hospitalized Patients With 2019 Novel Coronavirus-Infected Pneumonia in Wuhan, China. JAMA 323, 1061-1069.

54. Wessels I, Pupke JT, Trotha K-T von, et al. (2020) Zinc supplementation ameliorates lung injury by reducing neutrophil recruitment and activity. Thorax $\mathbf{7 5}, 253-261$.

55. Liu J, Liu Y, Xiang P, et al. (2020) Neutrophil-to-lymphocyte ratio predicts critical illness patients with 2019 coronavirus disease in the early stage. J Transl Med 18, 206.

56. Fraker PJ, King LE, Laakko T, et al. (2000) The dynamic link between the integrity of the immune system and zinc status. J Nutr 130, 1399S-1400S.

57. Sakakibara Y, Sato S, Kawashima Y, et al. (2011) Different recovery responses from dietary zinc-deficiency in the distribution of rat granulocytes. J Nutr Sci Vitaminol 57, 197-201.

58. Tillmann N, Rink L \& Wessels I The role of zinc in granulopoiesis. Submitted thesis. RWTH Aachen University, Medical Faculty (unpublished data).

59. Aster I, Barth L-M, Rink L, et al. (2019) Alterations in membrane fluidity are involved in inhibition of GM-CSF-induced signaling in myeloid cells by zinc. J Trace Elem Med Biol 54, 214-220.

60. Taneri PE, Gómez-Ochoa SA, Llanaj E, et al. (2020) Anemia and iron metabolism in COVID-19: a systematic review and meta-analysis. Eur J Epidemiol 35, 763-773.

61. Mir E, Hossein-nezhad E, Bahrami A, et al. (2007) Serum zinc concentration could predict bone mineral density and protect osteoporosis n healthy men. Iranian J Public Health 30-36.

62. Vallee BL \& Falchuk KH (1993) The biochemical basis of zinc physiology. Physiol Rev 73, 79-118.

63. Abdelhaleim AF, Abdo Soliman JS \& Amer AY (2019) Association of zinc deficiency with iron deficiency anemia and its symptoms: results from a case-control study. Cureus 11, e3811.

64. Fukushima T, Horike H, Fujiki S, et al. (2009) Zinc deficiency anemia and effects of zinc therapy in maintenance hemodialysis patients. Ther Apher Dial 13, 213-219.

65. Houghton LA, Parnell WR, Thomson CD, et al. (2016) Serum zinc is a major predictor of anemia and mediates the effect of selenium on hemoglobin in school-aged children in a Nationally Representative Survey in New Zealand. J Nutr 146, 1670-1676.

66. Shweta G, Prantesh J \& Shashvat S (2014) Isolated zinc deficiency causing severe microcytosis and sideroblastic anemia. Turk J Haematol 31, 339-340.

67. Kaneko S, Morino J, Minato S, et al. (2020) Serum zinc concentration correlates with ferritin concentration in patients undergoing peritoneal dialysis: a cross-sectional study. Front Med $\mathbf{7}$, 537586.

68. Yokoi K, Sandstead HH, Egger NG, et al. (2007) Association between zinc pool sizes and iron stores in premenopausal women without anaemia. Br J Nutr 98, 1214-1223.

69. Gombart AF, Pierre A \& Maggini S (2020) A review of micronutrients and the immune system-working in harmony to reduce the risk of infection. Nutrients $\mathbf{1 2}, 1$.

70. Viana MB (2011) Anemia and infection: a complex relationship. Rev Bras Hematol Hemoter 33, 90-92. 
71. Channappanavar R, Fehr AR, Vijay R, et al. (2016) Dysregulated type i interferon and inflammatory monocytemacrophage responses cause lethal pneumonia in SARSCoV-infected mice. Cell Host Microbe 19, 181-193.

72. Henderson LA, Canna SW, Schulert GS, et al. (2020) On the alert for cytokine storm: immunopathology in COVID-19. Arthritis Rheumatol 72, 1059-1063.

73. Conti P, Ronconi G, Caraffa A, et al. (2020) Induction of proinflammatory cytokines (IL-1 and IL-6) and lung inflammation by Coronavirus-19 (COVI-19 or SARS-CoV-2): anti-inflammatory strategies. J Biol Regul Homeost Agents 34, 2.

74. Chen G, Di Wu, Guo W, et al. (2020) Clinical and immunological features of severe and moderate coronavirus disease 2019. J Clin Invest 130, 2620-2629.

75. Ye Q, Wang B \& MaoJ (2020) The pathogenesis and treatment of the 'Cytokine Storm' in COVID-19. I Infect 80, 607-613.

76. Chousterman BG, Swirski FK \& Weber GF (2017) Cytokine storm and sepsis disease pathogenesis. Semin Immunopathol 39, 517-528.

77. Guan W-J, Ni Z-Y, Hu Y, et al. (2020) Clinical characteristics of coronavirus disease 2019 in China. NEngl JMed 382, 1708-1720.

78. Mehta P, McAuley DF, Brown M, et al. (2020) COVID-19: consider cytokine storm syndromes and immunosuppression. Lancet 395, 1033-1034.

79. Vinciguerra M, Romiti S, Fattouch K, et al. (2020) Atherosclerosis as pathogenetic substrate for Sars-Cov2 cytokine storm. J Clin Med $\mathbf{9}, 7$

80. Aziz M, Fatima R \& Assaly R (2020) Elevated interleukin-6 and severe COVID-19: a meta-analysis. JMed Virol 92, 2283-2285.

81. Di Giambenedetto S, Ciccullo A, Borghetti A, et al. (2020) Offlabel use of tocilizumab in patients with SARS-CoV-2 infection. J Med Virol 92, 1787-1788.

82. Cavalli G, Luca G de, Campochiaro C, et al. (2020) Interleukin-1 blockade with high-dose anakinra in patients with COVID-19, acute respiratory distress syndrome, and hyperinflammation: a retrospective cohort study. Lancet Rheumatol 2, e325-e331.

83. Feldmann M, Maini RN, Woody JN, et al. (2020) Trials of antitumour necrosis factor therapy for COVID-19 are urgently needed. Lancet 395, 1407-1409.

84. Reda R, Abbas AA, Mohammed M, et al. (2015) The interplay between Zinc, Vitamin D and, IL-17 in patients with Chronic Hepatitis C Liver disease. J Immunol Res 2015, 846348.

85. Bao B, Prasad AS, Beck FWJ, et al. (2010) Zinc decreases C-reactive protein, lipid peroxidation, and inflammatory cytokines in elderly subjects: a potential implication of zinc as an atheroprotective agent. Am J Clin Nutr 91, 1634-1641.

86. Bao B, Prasad AS, Beck FWJ, et al. (2003) Zinc modulates mRNA levels of cytokines. Am J Physiol Endocrinol Metab 285, E1095-102.

87. Bao S, Liu M-J, Lee B, et al. (2010) Zinc modulates the innate immune response in vivo to polymicrobial sepsis through regulation of NF-kappaB. Am J Physiol Lung Cell Mol Physiol 298, L744-L754.

88. Wessels I, Haase H, Engelhardt G, et al. (2013) Zinc deficiency induces production of the proinflammatory cytokines IL- $1 \beta$ and TNF $\alpha$ in promyeloid cells via epigenetic and redox-dependent mechanisms. J Nutr Biochem 24, 289-297.

89. Lienau S, Rink L \& Wessels I (2018) The role of zinc in calprotectin expression in human myeloid cells. J Trace Elem Med Biol 49, 106-112.

90. Prasad AS, Meftah S, Abdallah J, et al. (1988) Serum thymulin in human zinc deficiency. J Clin Invest 82, 1202-1210.

91. Tapazoglou E, Prasad AS, Hill G, et al. (1985) Decreased natural killer cell activity in patients with zinc deficiency with sickle cell disease. J Lab Clin Med 105, 19-22.
92. Meftah S \& Prasad AS (1989) Nucleotides in lymphocytes of human subjects with zinc deficiency. J Lab Clin Med 114, 114-119.

93. Prasad AS (2000) Effects of zinc deficiency on Th1 and Th2 cytokine shifts. I Infect Dis 182, S62-S68.

94. Finamore A, Roselli M, Merendino N, et al. (2003) Zinc deficiency suppresses the development of oral tolerance in rats. J Nutr 133, 191-198.

95. Rolles B, Maywald M \& Rink L (2018) Influence of zinc deficiency and supplementation on NK cell cytotoxicity. J Funct Foods 48, 322-328.

96. Wessels I, Maywald M \& Rink L (2017) Zinc as a gatekeeper of immune function. Nutrients 9,12

97. Öztürk G, Erbas D, Imir T, et al. (1994) Decreased natural killer (NK) cell activity in zinc-deficient rats. Gen Pharmacol 25, 1499-1503.

98. Sadighi A, Roshan MM, Moradi A, et al. (2008) The effects of zinc supplementation on serum zinc, alkaline phosphatase activity and fracture healing of bones. Saudi Med J 29, 1276-1279.

99. Wessels I (2017) Epigenetics and Minerals: an Overview. Patel, Preedy (Hg.) 2017 - Handbook of Nutrition. Basel: Springer International Publishing.

100. Rosenkranz E, Metz CHD, Maywald M, et al. (2016) Zinc supplementation induces regulatory $\mathrm{T}$ cells by inhibition of Sirt-1 deacetylase in mixed lymphocyte cultures. Mol Nutr Food Res 60, 661-671.

101. Wessels I \& Cousins RJ (2015) Zinc dyshomeostasis during polymicrobial sepsis in mice involves zinc transporter Zip14 and can be overcome by zinc supplementation. Am J Physiol Gastrointest Liver Physiol 309, G768-G778.

102. Kirtipal N \& Bharadwaj S (2020) Interleukin 6 polymorphisms as an indicator of COVID-19 severity in humans. J Biomol Struct Dyn 1-3.

103. Chen Y, Hu Y \& Song Z (2019) The association between interleukin-6 gene -174G/C single nucleotide polymorphism and sepsis: an updated meta-analysis with trial sequential analysis. BMC Med Genet 20, 35.

104. Mayor-Ibarguren A, Busca-Arenzana C \& Robles-Marhuenda Á (2020) A hypothesis for the possible role of zinc in the immunological pathways related to COVID-19 infection. Front Immunol 11, 1736

105. Mariani E, Neri S, Cattini L, et al. (2008) Effect of zinc supplementation on plasma IL-6 and MCP-1 production and NK cell function in healthy elderly: interactive influence of +647 MT1a and -174 IL-6 polymorphic alleles. Exp Gerontol 43, 462-471.

106. Grant RC, Rotstein C, Liu G, et al. (2020) Reducing dexamethasone antiemetic prophylaxis during the COVID-19 pandemic: recommendations from Ontario, Canada. Support Care Cancer 28, 5031-5036

107. Olnes MJ, Kotliarov Y, Biancotto A, et al. (2016) Effects of systemically administered hydrocortisone on the human immunome. Sci Rep 6, 23002.

108. Chen R-C, Tang X-P, Tan S-Y, et al. (2006) Treatment of severe acute respiratory syndrome with glucosteroids: the Guangzhou experience. Chest 129, 1441-1452.

109. Guo KJ, Zhao FC, Guo Y, et al. (2014) The influence of age, gender and treatment with steroids on the incidence of osteonecrosis of the femoral head during the management of severe acute respiratory syndrome: a retrospective study. Bone Joint J 96, 259-262.

110. Tang C, Wang Y, Lv H, et al. (2020) Caution against corticosteroid-based COVID-19 treatment. Lancet 395, 1759-1760.

111. Isidori AM, Arnaldi G, Boscaro M, et al. (2020) COVID-19 infection and glucocorticoids: update from the Italian Society of 
Endocrinology Expert Opinion on steroid replacement in adrenal insufficiency. J Endocrinol Invest 43, 1141-1147.

112. Garvy BA, King LE, Telford WG, et al. (1993) Chronic elevation of plasma corticosterone causes reductions in the number of cycling cells of the B lineage in murine bone marrow and induces apoptosis. Immunology 80, 587-592.

113. Cook RT, Schlueter AJ, Coleman RA, et al. (2007) Thymocytes, pre-B cells, and organ changes in a mouse model of chronic ethanol ingestion-absence of subset-specific glucocorticoidinduced immune cell loss. Alcohol: Clin Exp Res 31, $1746-1758$.

114. Taub DD \& Longo DL (2005) Insights into thymic aging and regeneration. Immunol Rev 205, 72-93.

115. Haase H \& Schomburg L (2019) You'd better zinc-trace element homeostasis in infection and inflammation. Nutrients 11, 9 .

116. Gammoh NZ \& Rink L (2017) Zinc in Infection and Inflammation. Nutrients 9,6 .

117. Gavriilaki E \& Brodsky RA (2020) Severe COVID-19 infection and thrombotic microangiopathy: success doesn't come easily. Br J Haematol 189, e227-e230.

118. Middeldorp S, Coppens M, van Haaps TF, et al. (2020) Incidence of venous thromboembolism in hospitalized patients with COVID-19. J Thromb Haemost 18, 1995-2002.

119. Cui S, Chen S, Li X, et al. (2020) Prevalence of venous thromboembolism in patients with severe novel coronavirus pneumonia. J Thromb Haemost 18, 1421-1424.

120. Lefrançais E, Ortiz-Muñoz G, Caudrillier A, et al. (2017) The lung is a site of platelet biogenesis and a reservoir for haematopoietic progenitors. Nature 544, 105-109.

121. Levi M, Thachil J, Iba T, et al. (2020) Coagulation abnormalities and thrombosis in patients with COVID-19. Lancet Haematol 7, e438-e440.

122. Nicolai L, Leunig A, Brambs S, et al. (2020) Immunothrombotic dysregulation in COVID-19 pneumonia is associated with respiratory failure and coagulopathy. Circulation 142, 11761189.

123. Kashi M, Jacquin A, Dakhil B, et al. (2020) Severe arterial thrombosis associated with Covid-19 infection. Thromb Res 192, 75-77.

124. Martin AI \& Rao G (2020) COVID-19: a potential risk factor for acute pulmonary embolism. Methodist Debakey Cardiovasc J 16, $155-157$

125. Beyrouti R, Adams ME, Benjamin L, et al. (2020) Characteristics of ischaemic stroke associated with COVID-19. J Neurol Neurosurg Psychiatr 91, 889-891.

126. Bavishi $\mathrm{C}$, Bonow RO, Trivedi $\mathrm{V}$, et al. (2020) Acute myocardial injury in patients hospitalized with COVID-19 infection: a review. Prog Cardiovasc Dis 63, 682-689.

127. Ziegler CG, Allon SJ, Nyquist SK, et al. (2020) SARS-CoV-2 receptor ACE2 is an interferon-stimulated gene in human airway epithelial cells and is detected in specific cell subsets across tissues. Cell 181, 1016-1035.

128. Knoell DL, Julian MW, Bao S, et al. (2009) Zinc deficiency increases organ damage and mortality in a murine model of polymicrobial sepsis. Crit Care Med 37, 1380-1388.

129. Knoell DL, Smith DA, Sapkota M, et al. (2019) Insufficient zinc intake enhances lung inflammation in response to agricultural organic dust exposure. J Nutr Biochem 70, 56-64.

130. Vu TT, Fredenburgh JC \& Weitz JI (2013) Zinc: an important cofactor in haemostasis and thrombosis. Thromb Haemost 109, 421-430.

131. Taylor KA \& Pugh N (2016) The contribution of zinc to platelet behaviour during haemostasis and thrombosis. Metallomics $\mathbf{8}$, 144-155.
132. Emery MP, Browning JD \& O'Dell BL (1990) Impaired hemostasis and platelet function in rats fed low zinc diets based on egg white protein. J Nutr 120, 1062-1067.

133. Gordon PR \& O'Dell BL (1983) Zinc deficiency and impaired platelet aggregation in guinea pigs. J Nutr 113, 239-245.

134. Marx G, Krugliak J \& Shaklai M (1991) Nutritional zinc increases platelet reactivity. Am J Hematol 38, 161-165.

135. Lopes-Pires ME, Ahmed NS, Vara D, et al. (2020) Zinc regulates reactive oxygen species generation in platelets. Platelets $1-10$

136. Bonow RO, Fonarow GC, O'Gara PT, et al. (2020) Association of coronavirus disease 2019 (covid-19) with myocardial injury and mortality. JAMA Cardiol 5, 751-753.

137. Lopez V, Keen CL \& Lanoue L (2008) Prenatal zinc deficiency: influence on heart morphology and distribution of key heart proteins in a rat model. Biol Trace Elem Res 122, 238-255.

138. Libby P (2006) Inflammation and cardiovascular disease mechanisms. Am J Clin Nutr 83, 456S-460S.

139. Connell P, Young VM, Toborek M, et al. (1997) Zinc attenuates tumor necrosis factor-mediated activation of transcription factors in endothelial cells. J Am Coll Nutr 16, 411-417.

140. Hennig B, Meerarani P, Toborek M, et al. (1999) Antioxidantlike properties of zinc in activated endothelial cells. J Am Coll Nutr 18, 152-158.

141. Reiterer G, MacDonald R, Browning JD, et al. (2005) Zinc deficiency increases plasma lipids and atherosclerotic markers in LDL-receptor-deficient mice. J Nutr 135, 2114-2118.

142. Gilden D, Cohrs RJ, Mahalingam R, et al. (2009) Varicella zoster virus vasculopathies: diverse clinical manifestations, laboratory features, pathogenesis, and treatment. Lancet Neurol $\mathbf{8}$, 731-740.

143. te Velthuis AJW, van den Worm SHE, Sims AC, et al. (2010) $\mathrm{Zn}(2+)$ inhibits coronavirus and arterivirus RNA polymerase activity in vitro and zinc ionophores block the replication of these viruses in cell culture. PLOS Pathog 6, e1001176.

144. Tomat AL, de los Ángeles Costa M \& Arranz CT (2011) Zinc restriction during different periods of life: influence in renal and cardiovascular diseases. Nutrition 27, 392-398.

145. Tubek S (2005) Zinc content in lymphocytes and the activity of zinc ion efflux from lymphocytes in primary arterial hypertension. BTER 107, 89-100.

146. Tubek S (2007) Role of zinc in regulation of arterial blood pressure and in the etiopathogenesis of arterial hypertension. Biol Trace Elem Res 117, 39-51.

147. Eide DJ (2011) The oxidative stress of zinc deficiency. Metallomics 3, 1124-1129.

148. Prasad AS (2009) Impact of the discovery of human zinc deficiency on health. J Am Coll Nutr 28, 257-265.

149. Cohen N \& Golik A (2006) Zinc balance and medications commonly used in the management of heart failure. Heart Fail Rev 11, 19-24

150. Little PJ, Bhattacharya R, Moreyra AE, et al. (2010) Zinc and cardiovascular disease. Nutr 26, 1050-1057.

151. Carrillo JLM, Rodríguez FPC, Coronado OG, et al. (2017) Physiology and Pathology of Innate Immune Response Against Pathogens. Physiology and Pathology of Immunology. London: InTechOpen.

152. Ruan Q, Yang K, Wang W, et al. (2020) Correction to: clinical predictors of mortality due to COVID-19 based on an analysis of data of 150 patients from Wuhan, China. Intensive Care Med 46, 1294-1297.

153. Chen N, Zhou M, Dong X, et al. (2020) Epidemiological and clinical characteristics of 99 cases of 2019 novel coronavirus pneumonia in Wuhan, China: a descriptive study. Lancet 395, 507-513. 
154. Roscioli E, Jersmann HP, Lester S, et al. (2017) Zinc deficiency as a codeterminant for airway epithelial barrier dysfunction in an ex vivo model of COPD. Int J Chron Obstruct Pulmon Dis 12, 3503-3510.

155. Hennig B, Wang Y, Ramasamy S, et al. (1992) Zinc deficiency alters barrier function of cultured porcine endothelial cells. J Nutr 122, 1242-1247.

156. Hennig B, Wang Y, Ramasamy S, et al. (1993) Zinc protects against tumor necrosis factor-induced disruption of porcine endothelial cell monolayer integrity. $J$ Nutr $\mathbf{1 2 3}$, 1003-1009.

157. Bao S \& Knoell DL (2006) Zinc modulates cytokine-induced lung epithelial cell barrier permeability. Am J Physiol Lung Cell Mol Physiol 291, L1132-41.

158. Yasui F, Kohara M, Kitabatake M, et al. (2014) Phagocytic cells contribute to the antibody-mediated elimination of pulmonary-infected SARS coronavirus. Virol 454-455, $157-168$.

159. Wessels I, Jansen J, Rink L, et al. (2010) Immunosenescence of polymorphonuclear neutrophils. Sci World J 10, 145-160.

160. Cowland JB \& Borregaard N (2016) Granulopoiesis and granules of human neutrophils. Immunol Rev 273, 11-28.

161. Grommes J \& Soehnlein O (2011) Contribution of neutrophils to acute lung injury. Mol Med 17, 293-307.

162. Briggs WA, Pedersen MM, Mahajan SK, et al. (1982) Lymphocyte and granulocyte function in zinc-treated and zinc-deficient hemodialysis patients. Kidney Int $\mathbf{2 1}$ 827-832.

163. Hasan R, Rink L \& Haase H (2016) Chelation of free $\mathrm{Zn}(2)(+)$ impairs chemotaxis, phagocytosis, oxidative burst, degranulation, and cytokine production by neutrophil granulocytes. Biol Trace Elem Res 171, 79-88.

164. Hasan R, Rink L \& Haase H (2013) Zinc signals in neutrophil granulocytes are required for the formation of neutrophil extracellular traps. Innate Immun 19, 253-264.

165. Kloubert V \& Rink L (2015) Zinc as a micronutrient and its preventive role of oxidative damage in cells. Food Funct $\mathbf{6}$, 3195-3204.

166. Maret W (2009) Molecular aspects of human cellular zinc homeostasis: redox control of zinc potentials and zinc signals. Biometals 22, 149-157.

167. Prasad AS, Bao B, Beck FWJ, et al. (2004) Antioxidant effect of zinc in humans. Free Radic Biol Med 37, 1182-1190.

168. Lee SR (2018) Critical role of zinc as either an antioxidant or a prooxidant in cellular systems. Oxid Med Cell Longev $\mathbf{2 0 1 8}$ 9156285.

169. O'Dell BL (2000) Role of zinc in plasma membrane function. J Nutr 130, 1432S-1436S.

170. Ramirez DC, Gomez-Mejiba SE, Corbett JT, et al. (2009) Cu, $\mathrm{Zn}$-Superoxide dismutase-driven free radical modifications: copper- and carbonate radical anion-initiated protein radical chemistry. Biochem J 417, 341-353.

171. Taylor CG, Bettger WJ \& Bray TM (1988) Effect of dietary zinc or copper deficiency on the primary free radical defense system in rats. J Nutr 118, 613-621.

172. Bray TM \& Bettger WJ (1990) The physiological role of zinc as an antioxidant. Free Radical Biol Med 8, 281-291.

173. Hegetschweiler K, Saltman P, Dalvit C, et al. (1987) Kinetics and mechanisms of the oxidation of myoglobin by $\mathrm{Fe}(\mathrm{III})$ and $\mathrm{Cu}(\mathrm{II})$ complexes. Biochim Biophys Acta 912, 384-397.

174. Aimo L, Cherr GN \& Oteiza PI (2010) Low extracellular zinc increases neuronal oxidant production through nadph oxidase and nitric oxide synthase activation. Free Radic Biol Med 48, 1577-1587.
175. Ludwig JC, Misiorowski RL, Chvapil M, et al. (1980) Interaction of zinc ions with electron carrying coenzymes NADPH and NADH. Chem Biol Interact 30, 25-34.

176. Verstraeten SV, Nogueira LV, Schreier S, et al. (1997) Effect of trivalent metal ions on phase separation and membrane lipid packing: role in lipid peroxidation. Arch Biochem Biophys 338, 121-127.

177. Friedrich LC, Mendes MA, Silva VO, et al. (2012) Mechanistic implications of zinc(II) ions on the degradation of phenol by the fenton reaction. J Braz Chem Soc 23, 1372-1377.

178. Zago MP, Verstraeten SV \& Oteiza PI (2000) Zinc in the prevention of $\mathrm{Fe} 2+$-initiated lipid and protein oxidation. Biol Res 33, $143-150$.

179. Jarosz M, Olbert M, Wyszogrodzka G, et al. (2017) Antioxidant and anti-inflammatory effects of zinc. Zinc-dependent NF-кB signaling. Inflammopharmacology 25, 11-24.

180. Wang S, Nie P, Lu X, et al. (2020) Nrf2 participates in the antiapoptotic role of zinc in Type 2 diabetic nephropathy through Wnt/ $\beta$-catenin signaling pathway. J Nutr Biochem 84, 108451.

181. Abdulhamid I, Beck FWJ, Millard S, et al. (2008) Effect of zinc supplementation on respiratory tract infections in children with cystic fibrosis. Pediatr Pulmonol 43, 281-287.

182. Cao J-W, Duan S-Y, Zhang H-X, et al. (2019) Zinc deficiency promoted fibrosis via ROS and TIMP/MMPs in the myocardium of mice. Biol Trace Elem Res 196, 145-152.

183. Petrilli CM, Jones SA, Yang J, et al. (2020) Factors associated with hospital admission and critical illness among 5279 people with coronavirus disease 2019 in New York City: prospective cohort study. BMJ 369, m1966.

184. Rodriguez-Morales AJ, Cardona-Ospina JA, GutiérrezOcampo E, et al. (2020) Clinical, laboratory and imaging features of COVID-19: a systematic review and meta-analysis. Travel Med Infect Dis 34, 101623.

185. Matthay MA, Zemans RL, Zimmerman GA, et al. (2019) Acute respiratory distress syndrome. Nat Rev Dis Primers 5, 18.

186. Hoeger J, Simon T-P, Beeker T, et al. (2017) Persistent low serum zinc is associated with recurrent sepsis in critically ill patients: a pilot study. PLoS One 12, e0176069.

187. Saleh NY \& Abo El Fotoh WMM (2018) Low serum zinc level: the relationship with severe pneumonia and survival in critically ill children. Int J Clin Pract 72, e13211.

188. Besecker BY, Exline MC, Hollyfield J, et al. (2011) A comparison of zinc metabolism, inflammation, and disease severity in critically ill infected and noninfected adults early after intensive care unit admission. Am J Clin Nutr 93, 1356-1364.

189. Eijkelkamp BA, Morey JR, Neville SL, et al. (2019) Dietary zinc and the control of Streptococcus pneumoniae infection. PLOS Pathog 15, e1007957.

190. Visalakshy J, Surendran S, Pillai MPG, et al. (2017) Could plasma zinc be a predictor for mortality and severity in sepsis syndrome? Int J Res Med Sci 5, 3929.

191. Saner G, Uğur Baysal S, Ünüvar E, et al. (2000) Serum zinc, copper levels, and copper/zinc ratios in infants with sepsis syndrome. J Trace Elem Exp Med 13, 265-270.

192. Barnett JB, Hamer DH \& Meydani SN (2010) Low zinc status: a new risk factor for pneumonia in the elderly? Nutr Rev $\mathbf{6 8}$, 30-37.

193. Alker W \& Haase H (2018) Zinc and Sepsis. Nutrients 10, 8.

194. Boudreault F, Pinilla-Vera M, Englert JA, et al. (2017) Zinc deficiency primes the lung for ventilator-induced injury. JCI Insight 2, 11.

195. Kamei S, Fujikawa H, Nohara H, et al. (2018) Zinc deficiency via a splice switch in zinc importer ZIP2/SLC39A2 causes cystic fibrosis-associated MUC5AC hypersecretion in airway epithelial cells. EBioMedicine 27, 304-316. 
196. Bhat MH, Rather AB, Dhobi GN et al. (2016) Zinc Levels in community acquired pneumonia in hospitalized patients; a case control study. EgyptJ Chest Dis Tuberculosis 65, 485-489.

197. Meydani SN, Barnett JB, Dallal GE, et al. (2007) Serum zinc and pneumonia in nursing home elderly. Am J Clin Nutr 86, $1167-1173$.

198. Vogel-González M, Talló-Parra M, Herrera-Fernández V, et al. (2021) Low zinc levels at admission associates with poor clinical outcomes in SARS-CoV-2 infection. Nutrients 13, 562.

199. Gheblawi M, Wang K, Viveiros A, et al. (2020) AngiotensinConverting enzyme 2: SARS-CoV-2 receptor and regulator of the renin-angiotensin system: celebrating the 20th anniversary of the discovery of ACE2. Circ Res 126, 1456-1474.

200. Haga S, Yamamoto N, Nakai-Murakami C, et al. (2008) Modulation of TNF-alpha-converting enzyme by the spike protein of SARS-COV and ACE2 induces TNF- $\alpha$ production and facilitates viral entry. Proc Natl Acad Sci USA 105, 7809-7814.

201. Reeves PG \& O'Dell BL (1986) Effects of dietary zinc deprivation on the activity of angiotensin-converting enzyme in serum of rats and guinea pigs. $J$ Nutr 116, 128-134.

202. Apgar J \& Everett GA (1991) Low zinc intake affects maintenance of pregnancy in guinea pigs. J Nutr 121, 192-200.

203. Takeda N, Takaoka T, Ueda C, et al. (2004) Zinc deficiency in patients with idiopathic taste impairment with regard to angiotensin converting enzyme activity. Auris Nasus Larynx $\mathbf{3 1}$, 425-428.

204. Reeves PG \& O'Dell BL (1988) Zinc deficiency in rats and angiotensin-converting enzyme activity: comparative effects on lung and testis. J Nutr 118, 622-626.

205. Min J, Landry J, Sternglanz R, et al. (2001) Crystal structure of a SIR2 Homolog-NAD complex. Cell 105, 269-279.

206. Chakrabarty SP \& Balaram H (2010) Reversible binding of zinc in Plasmodium falciparum Sir2: structure and activity of the apoenzyme. Biochim Biophys Acta 1804, 1743-1750.

207. Chen Y-T, Shao S-C, Hsu C-K, et al. (2020) Incidence of acute kidney injury in COVID-19 infection: a systematic review and meta-analysis. Crit Care 24, 346.

208. Argenziano MG, Bruce SL, Slater CL, et al. (2020) Characterization and clinical course of 1000 patients with coronavirus disease 2019 in New York: retrospective case series. BMJ 34, m1996.

209. Kurihara N, Yanagisawa H, Sato M, et al. (2002) Increased renal vascular resistance in zinc-deficient rats: role of nitric oxide and superoxide. Clin Exp Pharmacol Physiol 29, 1096-1104.

210. Yanagisawa H, Moridaira K \& Wada O (2000) Zinc deficiency further increases the enhanced expression of endothelin-1 in glomeruli of the obstructed kidney. Kidney Int 58, 575-586.

211. Yanagisawa H, Nodera M \& Wada O (1998) Zinc deficiency aggravates tubulointerstitial nephropathy caused by ureteral obstruction. Biol Trace Elem Res 65, 1-6.

212. Cabral PC, Diniz AdS \& Arruda IKG de (2005) Vitamin A and zinc status in patients on maintenance haemodialysis. Nephrology 10, 459-463.

213. Skrovanek S (2014) Zinc and gastrointestinal disease. WJGP 5, 496.

214. Wapnir RA (2000) Zinc deficiency, malnutrition and the gastrointestinal tract. J Nutr 130, 1388S-1392S.

215. Maares M \& Haase H (2020) A guide to human zinc absorption: general overview and recent advances of In Vitro intestinal models. Nutrients 12, 3 .

216. Maguire M \& Maguire G (2019) Gut dysbiosis, leaky gut, and intestinal epithelial proliferation in neurological disorders: towards the development of a new therapeutic using amino acids, prebiotics, probiotics, and postbiotics. Rev Neurosci 30, 179-201.

217. Anders H-J, Andersen K \& Stecher B (2013) The intestinal microbiota, a leaky gut, and abnormal immunity in kidney disease. Kidney Int 83, 1010-1016.

218. Sturniolo GC, D'Inca R, Parisi G, et al. (1992) Taste alterations in liver cirrhosis: are they related to zinc deficiency? J Trace Elem Electrolytes Health Dis 6, 15-19.

219. World Health Organization (2006) Implementing the New Recommendations of the Clinical Management of Diarrhoea. Geneva: WHO.

220. Kogan S, Sood A \& Garnick MS (2017) Zinc and wound healing: a review of zinc physiology and clinical applications. Wounds 29, 102-106.

221. Khorasani G, Hosseinimehr SJ \& Kaghazi Z (2008) The alteration of plasma's zinc and copper levels in patients with burn injuries and the relationship to the time after burn injuries. Singap Med J 49, 627-630.

222. Binnebösel M, Grommes J, Koenen B, et al. (2010) Zinc deficiency impairs wound healing of colon anastomosis in rats. Int J Colorectal Dis 25, 251-257.

223. Aydemir TB, Sitren HS \& Cousins RJ (2012) The zinc transporter Zip14 influences c-Met phosphorylation and hepatocyte proliferation during liver regeneration in mice. Gastroenterology 142, 1536-1546.e5.

224. Karagulova G, Yue Y, Moreyra A, et al. (2007) Protective role of intracellular zinc in myocardial ischemia/reperfusion is associated with preservation of protein kinase $\mathrm{C}$ isoforms. J Pharmacol Exp Ther 321, 517-525.

225. Turan B \& Tuncay E (2017) Impact of labile zinc on heart function: from physiology to pathophysiology. Int JMol Sci 18, 11.

226. Choi BY, Jung JW \& Suh SW (2017) The emerging role of zinc in the pathogenesis of multiple sclerosis. Int J Mol Sci 18, 10.

227. Ellul MA, Benjamin L, Singh B, et al. (2020) Neurological associations of COVID-19. Lancet Neurol 19, 767-783.

228. Paterson RW, Brown RL, Benjamin L, et al. (2020) The emerging spectrum of COVID-19 neurology: clinical, radiological and laboratory findings. Brain 143, 3104-3120.

229. Andrews RC (1992) An update of the zinc deficiency theory of schizophrenia. Identification of the sex determining system as the site of action of reproductive zinc deficiency. Med Hypotheses 38, 284-291.

230. Szewczyk B, Kubera M \& Nowak G (2011) The role of zinc in neurodegenerative inflammatory pathways in depression. Prog Neuro-Psychopharmacol Biol Psychiatr 35, 693-701.

231. Brewer GJ, Kanzer SH, Zimmerman EA, et al. (2010) Subclinical zinc deficiency in Alzheimer's disease and Parkinson's disease. Am J Alzheimers Dis Other Demen 25, 572-575.

232. Roy A, Evers SE, Avison WR, et al. (2010) Higher zinc intake buffers the impact of stress on depressive symptoms in pregnancy. Nutr Res 30, 695-704.

233. Munshi A, Babu S, Kaul S, et al. (2010) Depletion of serum zinc in ischemic stroke patients. Methods Find Exp Clin Pharmacol 32, 433-436.

234. Bhatt A, Farooq MU, Enduri S, et al. (2011) Clinical significance of serum zinc levels in cerebral ischemia. Stroke Res Treat 2010, 245715.

235. Pochwat B, Domin H, Rafało-Ulińska A, et al. (2020) Ketamine and Ro 25-6981 reverse behavioral abnormalities in rats subjected to dietary zinc restriction. Int J Mol Sci $\mathbf{2 1}, 13$.

236. Seth R, Corniola RS, Gower-Winter SD, et al. (2015) Zinc deficiency induces apoptosis via mitochondrial p53- and caspasedependent pathways in human neuronal precursor cells. J Trace Elem Med Biol 30, 59-65. 
237. Cole TB, Robbins CA, Wenzel HJ, et al. (2000) Seizures and neuronal damage in mice lacking vesicular zinc. Epilepsy Res 39, 153-169.

238. Blasco-Ibáñez J-M, Poza-Aznar J, Crespo C, et al. (2004) Chelation of synaptic zinc induces overexcitation in the hilar mossy cells of the rat hippocampus. Neurosci Lett 355, 101-104.

239. Weiss JH, Sensi SL \& Koh JY (2000) Zn2+: a novel ionic mediator of neural injury in brain disease. Trends Pharmacol Sci $\mathbf{2 1}$, 395-401.

240. Horning MS \& Trombley PQ (2001) Zinc and copper influence excitability of rat olfactory bulb neurons by multiple mechanisms. J Neurophysiol 86, 1652-1660.

241. Sekler I, Moran A, Hershfinkel M, et al. (2002) Distribution of the zinc transporter ZnT-1 in comparison with chelatable zinc in the mouse brain. J Comp Neurol 447, 201-209.

242. Choi BY, Hong DK, Jeong JH, et al. (2020) Zinc transporter 3 modulates cell proliferation and neuronal differentiation in the adult hippocampus. Stem Cells 38, 994-1006.

243. Chowanadisai W, Kelleher SL \& Lönnerdal B (2005) Zinc deficiency is associated with increased brain zinc import and LIV-1 expression and decreased ZnT-1 expression in neonatal rats. J Nutr 135, 1002-1007.

244. Stoltenberg M, Bush AI, Bach G, et al. (2007) Amyloid plaques arise from zinc-enriched cortical layers in APP/PS1 transgenic mice and are paradoxically enlarged with dietary zinc deficiency. Neuroscience 150, 357-369.

245. Datki Z, Galik-Olah Z, Janosi-Mozes E, et al. (2020) Alzheimer risk factors age and female sex induce cortical $\mathrm{A} \beta$ aggregation by raising extracellular zinc. Mol Psychiatry 25, 2728-2741.

246. Kumar V (2016) Zinc deficiency and its effect on the brain: an update. Int J Mol Genet Gene Ther 1, 1.

247. Gilgun-Sherki Y, Melamed E \& Offen D (2004) The role of oxidative stress in the pathogenesis of multiple sclerosis: the need for effective antioxidant therapy. J Neurol 251, 261-268.

248. Beltran-Corbellini A, Chico-Garcia JL, Martinez-Poles J, et al. (2020) Acute-onset smell and taste disorders in the context of Covid-19: a pilot multicenter PCR-based case-control study. Eur J Neurol 27, e33.

249. Lechien JR, Hopkins C \& Saussez S (2020) Sniffing out the evidence; It's now time for public health bodies recognize the link between COVID-19 and smell and taste disturbance. Rhinology 58, 402-403.

250. Moein ST, Hashemian SMR, Mansourafshar B, et al. (2020) Smell dysfunction: a biomarker for COVID-19. Int Forum Allergy Rhinol 10, 944-995.

251. Russell B, Moss C, Rigg A, et al. (2020) Anosmia and ageusia are emerging as symptoms in patients with COVID-19: what does the current evidence say? Ecancermedicalscience 14, ed98.

252. Russell RM, Cox ME \& Solomons N (1983) Zinc and the special senses. Ann Intern Med 99, 227-239.

253. Lyckholm L, Heddinger SP, Parker G, et al. (2012) A randomized, placebo controlled trial of oral zinc for chemotherapyrelated taste and smell disorders. I Pain Palliat Care Pharmacother 26, 111-114.

254. Calder PC, Carr AC, Gombart AF, et al. (2020) Optimal nutritional status for a well-functioning immune system is an important factor to protect against viral infections. Nutrients 12, 4 .
255. Handu D, Moloney L, Rozga M, et al. (2020) Malnutrition care during the COVID-19 pandemic: considerations for registered dietitian nutritionists. J Acad Nutr Diet (Epublication ahead of print version 14 May 2020).

256. Leij-Halfwerk S, Verwijs MH, van Houdt S, et al. (2019) Prevalence of protein-energy malnutrition risk in European older adults in community, residential and hospital settings, according to 22 malnutrition screening tools validated for use in adults $\geq 65$ years: a systematic review and meta-analysis. Maturitas 126, 80-89.

257. ctri.nic.in/ (2020) To Determine the Efficacy of An Ayurvedic Preparation Raj Nirwan Bati (RNB) on symptomatic COVID19 Patients: A Double-Blind Randomized Controlled Trial: efficacy of An Ayurvedic Preparation Raj Nirwan Bati (RNB) on symptomatic COVID-19 Patient. http://ctri.nic.in/ Clinicaltrials/showallp.php? $\operatorname{mid} 1=44707 \&$ EncHid $=$ \&user Name $=2020 / 06 / 025998$ (accessed July 2020).

258. Jothimani D, Kailasam E, Danielraj S, et al. (2020) COVID-19: poor outcomes in patients with zinc deficiency. Int J Infect Dis 100, 343-349.

259. Anuk AT, Polat N, Akdas S, et al. (2020) The relation between trace element status (zinc, copper, magnesium) and clinical outcomes in COVID-19 infection during pregnancy. Biol Trace Elem Res 1-10.

260. Yasui Y, Yasui H, Suzuki K, et al. (2020) Analysis of the predictive factors for a critical illness of COVID-19 during treatment - relationship between serum zinc level and critical illness of COVID-19. Int J Infect Dis 100, 230-236.

261. ClinicalTrials.gov (2020) Evaluation of the Relationship Between Zinc Vitamin D and b12 Levels in the Covid-19 Positive Pregnant Women. https://ClinicalTrials.gov/show/ NCT0 4407572 (accessed May 2020).

262. Finzi E (2020) Treatment of SARS-CoV-2 with high dose oral zinc salts: a report on four patients. Int J Infect Dis 99, 307-309.

263. Yao JS, Paguio JA, Dee EC, et al. (2020) The minimal effect of zinc on the survival of hospitalized patients with Covid-19: an observational study. Chest 159, 108-111.

264. Frontera JA, Rahimian JO, Yaghi S, et al. (2020) Treatment with Zinc is associated with reduced in-hospital mortality among COVID-19 patients: a multi-center cohort study. Res Sq (Epublication ahead of print version 26 October 2020).

265. Kamran SM, Mirza Z-e-H, Naseem A, et al. (2020) Clearing the fog: is Hydroxychloroquine effective in reducing Corona virus disease-2019 progression: a randomized controlled trial. medRxiv (Epublication ahead of print version 11 October 2020).

266. Abd-Elsalam S, Soliman S, Esmail ES, et al. (2020) Do zinc supplements enhance the clinical efficacy of hydroxychloroquine?: a randomized, multicenter trial. Biol Trace Elem Res, 1-5 (Epublication ahead of print version 27 Nov 2020).

267. Derwand R \& Scholz M (2020) Does zinc supplementation enhance the clinical efficacy of chloroquine/hydroxychloroquine to win todays battle against COVID-19? Med Hypotheses 142, 109815.

268. Carlucci PM, Ahuja T, Petrilli C, et al. (2020) Zinc sulfate in combination with a zinc ionophore may improve outcomes in hospitalized COVID-19 patients. J Med Microbiol 69, 1228-1234. 